\title{
ESKİ İZMİR SİNEMALARI VE YILDIZ SİNEMASI: MEKÂN, TOPLUM, SEYIR
}

\author{
Dilek Kaya \\ Yaşar Üniversitesi İletişim Fakültesi
}

Öz

Bu çalışma, "yeni sinema tarihi" yaklaşımından hareketle, 1950-1980 yllları arasında İzmir'de sinema ve sinemaya gitme kültürünü inceliyor. Çalışmada, dönemin en büyük ve en popüler kapalı sinema salonlarından olup bugün hâlâ ayakta olan yorgun ve harap binasında halı saha, bilardo ve masa tenisi salonu olarak hizmet veren "Ylldız Sineması" (1953-1988) üzerinde özel olarak duruluyor. Yerel Yeni Asır gazetesi taramaları ve 34 kişi ile yapllmış sözlü tarih araştırma yönteminden yola çıkan görüşmelerden elde edilen nitel verilerden hareketle, İzmir'in gündelik hayatı içerisinde sinemanın nasıl bir kamusal alan, sosyal olay ve seyir alanı olduğu inceleniyor. Çalışma, söz konusu dönemde, kentteki sinema seyircisinden homojen bir kitle ve sinemanin sosyal deneyiminden tek tip bir deneyim olarak bahsedilemeyeceğini gösteriyor ve yaş, toplumsal cinsiyet, sosyoekonomik sınıf ve beğeni (taste) farklılıklarından kaynaklı farklı deneyim süreçlerinin altını çiziyor. Bu şekilde, sinemanın bir toplu eğlence ve haz alanı olduğu kadar, çeşitli karşılaşmaların ve çatışmaların yaşandığı bir mücadele alanı olduğuna da işaret ediliyor.

Anahtar Sözcükler: İzmir sinemaları, sinemaya gitme kültürü, kamusal alan, sosyal deneyim, seyir.

Bu çalışma 20 Nisan 2017 tarihinde sinecine dergisine ulaşmış, 15 Haziran 2017 tarihinde kabul almıştır. dilek.kaya@yasar.edu.tr 


\title{
Old Cinemas of Izmir and Ylldız Cinema: Space, Society, Spectatorship
}

\begin{abstract}
Inspired by "new cinema history," this study explores cinema and the culture of movie-going in Izmir between 1950 and 1980. Special attention is paid to the Ylldız Cinema (1953-1988), which now features an astro-pitch, billiard hall, and ping-pong hall in its old and tired building. Based on qualitative data obtained from the local newspaper Yeni Asir and from interviews with 34 people, the study examines cinema as public space, social event, and field of spectatorship in context of Izmir's everyday life. It argues that cinema audiences in the period studied were not a homogeneous mass. Nor was the social experience of cinema a monotype experience. The study examines various types of experience depending on age, gender, socioeconomic class, and taste. Thus, it suggests that cinema is not only a field of collective entertainment and pleasure but also a field of struggle, incorporating diverse encounters and conflicts.
\end{abstract}

Keywords: Izmir cinemas, culture of movie-going, public space, social experience, spectatorship. 


\section{Giriş $^{1}$}

Seksenli yılların ortasında, sinemanın sadece filmler, türler ve yönetmenlerle sinırlandırılamayacak kadar kapsamlı ve katmanlı bir toplumsal olay olduğu tezinden hareketle, yeni bir sinema tarihi yazımı düşüncesi ortaya atıldı (Allen \& Gomery, 1985). Özellikle daha önceki sinema tarihlerinde görmezden gelinen sinema salonları, sinemaya gitme edimi ve izleyici deneyimlerini de araştırma konusu haline getirecek olan bu "yeni sinema tarihi" (new cinema history) çağrısı, doksanlı yllların sonundan itibaren Kuzey Amerika, Avustralya ve Avrupa akademik çevrelerinde geniş cevap buldu (Stokes \& Maltby, 1999a, 1999b, 2001, 2004; Maltby, Biltereyst \& Meers, 2011; Biltereyst, Maltby \& Meers, 2012). Bugün, yeni sinema tarihi çalışmaları, görece kısa geçmişine rağmen, önemli sayıda kitap ve makaleyle belli bir olgunluğa erişmiş durumdadır (Biltereyst, Lotze, \& Meers, 2012; Biltereyst \& Meers, 2016). $\mathrm{Bu}$ olgunluğa ve verimliliğe rağmen, Kuzey Amerika, Avustralya ve Avrupa ötesi toplumlarda sinemanın sosyal deneyimini, sinema salonlarını ve sinemaya gitme kültürünü ele alan çalışmaların halen sınırlı sayıda olduğu gözlemlenmektedir. Türkiye'de ise bu yönde yapılmış çalışmalar, yok olmamakla birlikte, henüz gelişim aşamasındadır (Aydın, 2008; Erdoğan, 2010; Öztürk, 2013; Ertaylan, 2013; Akbulut, 2014; Liman, 2014; Altınöz, 2015; Boran, 2015).

Bu çalışma, yeni sinema tarihi yaklaşımından hareketle, ellili yıllardan seksenli yıllara dek çok sayıda kapalı ve yazlık sinemasıyla canlı bir sinema kültürüne ev sahipliği yapmış olan İzmir'e odaklanıyor ve 1950-1980 yllları arasında İzmir'de sinema ve sinemaya gitme kültürünü inceliyor. ${ }^{2}$ Çalışma, dönemin en büyük ve en popüler kapalı sinema

1 Bu çalışma Yaşar Üniversitesi Proje Değerlendirme Komisyonu (PDK) tarafından kabul edilen BAPo3ı no.lu proje kapsamında desteklenmiştir. Projede Dilek Kaya yürütücü, Ezgi Albayrakoğlu araştırmacı olarak yer almıştır.

2 İzmir'de sinema ile ilgili kapsamlı çalışmalar mevcuttur. Oğuz Makal'ın 1999 tarihli Tarih İçinde İzmir Sinemaları adlı kitabı ve araştırmacı yazar Yaşar Ürük'ün 2011-2013 yılları arasında İzmir Life dergisi için hazırlamış olduğu "Sinema Cenneti İzmir" başlıklı yazı dizisi bu bağlamda önemli kaynaklardır. Zuhal Çetin Özkan'ın Basmane'nin Orta Yeri Sinema (2010) adlı belgesel filmi de alana önemli bir katkıdır. Bunların yanı sıra, çeşitli semt kitaplarında, dergi yazılarında ve röportajlarda İzmir sinemalarıyla ilgili anılara yer verildiği de görülür Bkz. Ergir (1999); Özdemir (2012); Yentürk (2003); Ürük (2003). Tüm bu kaynaklar, eski İzmir sinemaları hakkında önemli bilgiler içermekle birlikte, sinemanın sosyal deneyimini kapsam dişında tutmaktadırlar. 


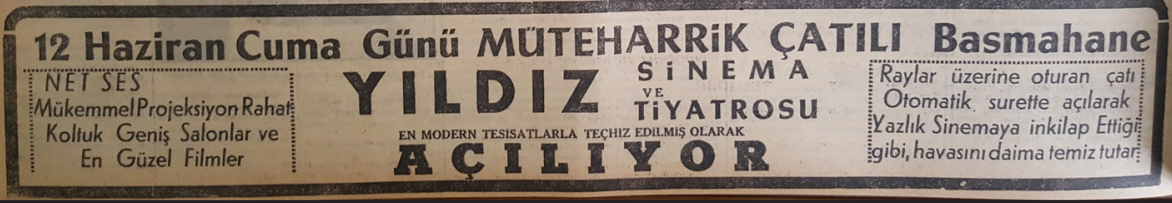

salonlarından olup bugün hâlâ ayakta olan yorgun ve harap binasında halı saha, bilardo ve masa tenisi salonu olarak hizmet veren "Yıldız Sineması" (1953-1988) üzerinde özel olarak duruyor. İzmir'in gündelik hayatı içerisinde sinemanın nasıl bir kamusal alan, sosyal olay ve seyir alanı olduğunu anlamaya ve anlamlandırmaya yönelik çalışma, Türkiye'de ve dünyadaki yeni sinema tarihi çalışmalarına olduğu kadar, Türkiye bağlamında sosyokültürel tarih, toplumsal hafıza ve kent hafızasına da özgün bir katkı olmayı hedefliyor.

Çalışma, yorumlayıcı yaklaşıma dayanan nitel bir araştırma niteliğindedir. Çalışmanın birincil kaynaklarını, Haziran 2016-Şubat 2017 tarihleri arasında sürdürülmüş, "Yıldız Sineması: İzmir Sinema Kültürü Üzerinde Bir Mikro-tarih Araştırması" adlı bir bilimsel araştırma projesi kapsamında yapılmış yerel Yeni Asır gazetesi taramaları ve sözlü tarih araştırma yönteminden yola çıkan görüşmelerden elde edilmiş nitel veriler oluşturmaktadır. Yaşları 51-91 arasında değişen 34 kişiyle yapılmış görüşmeler, Eylül 2016-Şubat 2017 arasında, görüşmecilerin evlerinde veya iş yerlerinde gerçekleştirilmiş, süreleri görüşmecilerin anlatma kapasitelerine bağlı olarak 50-90 dakika arasında değişen, yarı-yapılandırılmış görüşmelerdir. Kısmen de olsa sinema seyircilerini temsilen görüşülen 27 kişi (16 kadın, 11 erkek); Yıldız Sineması'nın

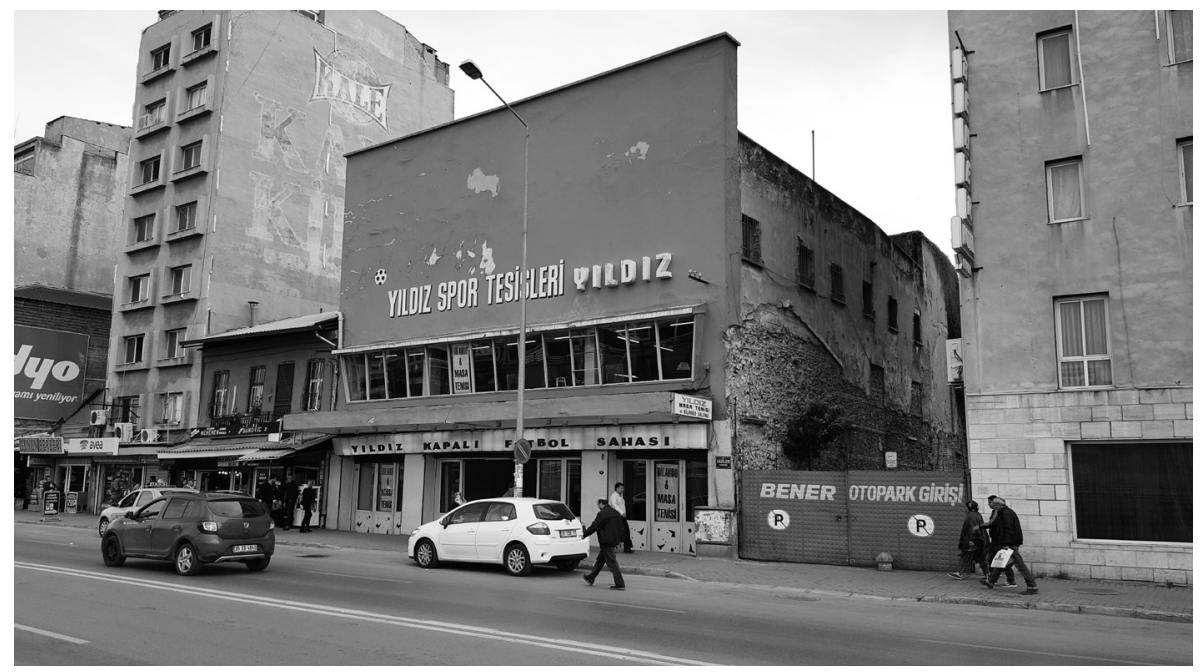


bulunduğu Basmaneli semt esnafları, tanıdıklar aracılığıyla bulunup ulaşılmış İzmir'de söz konusu dönemlerde aktif şekilde sinemaya giden kişiler ve bir huzur evinin sakinlerinden oluşmaktadır. Bu kişilerin sosyoekonomik olarak orta ve üst-orta s1nıfları temsil ettikleri söylenebilir. Diğer yedi görüşmecinin tamamı Ylldız Sineması ile ilişkili kişilerdir: Yıldız Sineması'nın halen hayatta olan sahibi Yüksel Kazmirci (87) ve oğlu Tolga Kazmirci (58); 1982 yılına dek sinemanın müdürlüğünü yapmış Oğuz Işıkalp'in oğlu Osman Işıkalp (51); 1961-1965 yılları arası sinemada gişe memuru Ülfet Işıkalp (74); 1972-1976 yılları arasında sinemada gişe memuru Nadide Özdemir (63);

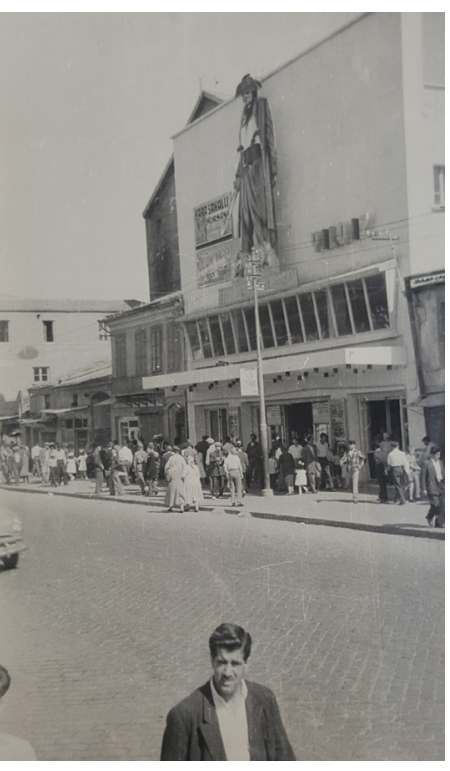
1959-1988 yllları arasında sinemanın baş makinisti Rüstem Çetin (82) ve 1970-1973 yılları arasında makinist yardımcısı Ferruh Özdemir (67). Görüşmecilerden elde edilen sözlü veriler metin haline getirilerek nitel içerik analizine tabi tutulmuştur. Gerek gazete taramaları ve görüşmeler sırasında ortaya çıkan verilerin genişliği, gerekse görüşmecilerin geçmiş sinema deneyimlerini anlatırken sık sık Yıldız Sineması ötesine geçmeleri, hatta bazen hatırladıkları bir anekdotu veya deneyimi belli bir sinemayla özdeşleştirememeleri nedeniyle, çalışmanın kapsamının geniş tutulması, bununla birlikte yer yer Yıldız Sineması üzerinde yoğunlaşılması uygun görülmüştür. ${ }^{3}$

Bu çalışmada, yukarıda bahsi geçen bilimsel araştırma projesinin bulgularının kapsamlı bir haritasının çıkarılmasına öncelik verilmiştir. Bu yaklaşım, bazı bulguların daha ayrıntılı ve derinlikli bir şekilde tartışılmasını sınırlamakla birlikte, sinemanın kapsamlı ve katmanlı bir olay oluşunun ve sinemanın sosyal deneyiminin heterojenliğinin ortaya konulması ve bu yolla, ilgili literatürde daha önce yeterince dikkate alınmamış noktalara işaret edilebilmesi açısından gerekli görülmüştür. Söz konusu olay ve deneyim haritası, ileride yapılacak çalışmalara ufuk açacak bir başlangıç haritası olarak düşünülmelidir.

3 Görüşmecilerden yapılan alıntılar, aksi belirtilmedikçe, sadece Yıldız Sineması'na özgü değildir. Görüşmecilerin sinemaya yoğun olarak gittikleri yıllar altmışlı yıllardır. 


\section{İzmir'in Eğlence Hayatında Sinema}

Türkiye'de siyasetten ekonomiye önemli dönüşümlerin yaşandığı ellili yıllar, diğer büyük şehirlerde olduğu gibi İzmir'de de kentleşmenin hızlandığı yıllardır. Bu dönemde kentin eğlence yerleri Kültürpark, Kordon ve Basmane'de yoğunlaşmıştır. Kentin merkezinde 430 bin metrekarelik alana yayılmış, her yıl 20 Ağustos-20 Eylül tarihleri arasında İzmir Enternasyonal Fuarı'na da ev sahipliği yapan Kültürpark; atlı Spor Kulübü, Tenis Kulübü, Sergi Sarayı gibi mekânların ve açık alanların yanı sıra, çay bahçeleri ve gazinoları bünyesinde barındırır. Kordon'da Tayyare Sineması, gece kulüpleri ve barlar; Basmane'de ise bar ve meyhanelerin yanı sıra Yıldız, İkbal, Kulüp ve Büyük sinemaları bulunmaktadır (Gölgesiz Gedikler, 2006, s. 516). Bar, meyhane ve gece kulüpleri genellikle erkeklerin tercih ettikleri yerler olup çay bahçeleri, gazinolar ve sinemalar ailecek gidilebilecek başlıca eğlence mekânlarıdır. 1955 yılında İzmir Belediyesi'nin kentte eğlence yerlerinin artırılması amacıyla Kültürpark ve bazı belediye arsalarını "gazino ve sinema gibi yerler" açacaklara sunması, bu dönemde gazinoların ve sinemaların toplumsal eğlence biçimlerinin iki ana ayağını oluşturduğunu gösterir. ${ }^{4} \mathrm{Bu}$ durumun yetmişlerin sonuna kadar devam ettiği görülür.

Altmışlı yılların başında, Yeni Asır gazetesinde, "İzmir' in gece hayatını nasıl buluyorsunuz?" başlıklı ankette, orta halli İzmirliler, yazın Fuar'da güzel vakit geçirebilmekle birlikte kışın sinema dışında hiçbir alternatif bulamadıklarından yakınmaktadırlar. Pavyon ve gazinoların ekonomik açıdan aileler için uygun olmaması; tiyatroda bütün bir mevsim aynı temsilin verilmesi; ailenin gidebileceği temiz veya ekonomik lokallerin olmayışı ve lunapark gibi eğlence yerlerinin eksikliği, ankete katılanların, neden kendilerini "sinemaya mahkûm" gördüklerini açıklarken ileri sürdükleri sebeplerdir. ${ }^{5}$ Sinema ve gazino dışında fazla eğlence alternatifinin olmayışı ve sinemaların gazinolara göre kıyaslanmayacak derecede ucuz oluşu, sinemayı halk arasında popüler yapan başat etmenlerden biri olarak düşünülegelmiştir. Bununla birlikte, bu çalışmanın sözlü tarih ayağında görüştüğümüz Alev Ersoy'un (78) aşağıdaki açıklaması, sinemanın, gazino gibi daha pahalı eğlence biçimlerini yaşayabilen kesimler için de daha sık yapılabilen bir boş zaman aktivitesi olarak ayrı bir öneme sahip olduğunu gösterir:

\footnotetext{
4 Sinema ve Eğlence Yerleri Yaptıracaklara Kolaylık (1955, 25 Ocak). Yeni Asır, 2.

5 İzmir'in Gece Hayatını Nasıl Buluyorsunuz? (1962, 4 Eylül), Yeni Asır, 3.
} 
Ali Ulvi'ye giderdik. ${ }^{6}$ Konserler falan olurdu. Sosyal hayatımız çok iyiydi. Fuarın çay bahçesi, gazinoları vardı. Dedem açık görüşlü ve meraklı biriydi. Ada Gazinosu'na senede 3-4 kere giderdik. Fuar açlınca Fuar'a giderdik. Biz çocuklar eşek arabalarına binerdik. Ama en başta sinemalar gelirdi çünkü başka eğlence yoktu.

İzmir'in sıcak ikliminde, yazlık açık hava sinemaları ayrıca bir cazibeye sahiptir. 1962'de "Geceleri sokağa çlkabiliyor musunuz?" konulu bir ankete cevaben, bir genç kız, bir şey olur korkusuyla ailesinin kendisini sinemaya bile götürmediğini belirtirken; bir ev hanımı, hırsızlar olmasa gece sinemaya veya komşuya gidebileceklerine değinmekte, fakat daha önce iki defa evi soyulduğu için artık saat sekizden sonra evi boş bırakmadıklarını söylemektedir. ${ }^{7}$ Altmışlı yıllarda, Yeni Asır gazetesinde, gece sinemada iken evleri soyulanlara dair çeşitli haberlere rastlanır. ${ }^{8} \mathrm{Bu}$ haberler, televizyonun ve televizyon yayınının henüz yaygınlaşmadığı bu dönemlerde, özellikle orta sınıf aileler için, sinemaya gitmenin ev/komşu ziyaretleri dişında geceleri ailecek yapılabilecek tek dışarı aktivitesi oluşunun altını çizer. Bu durum, Tanzer Başer Ökte (65) örneğinde olduğu gibi, görüşmelerde de dile getirilmiştir: "Sinemaya gidilecek akşam misafir gelir, onu da götürürdük. Çok önemliydi. Başka bir şey yoktu çünkü."

Altmışlı ve yetmişli yıllarda sinemalara olan ilgiyi göstermesi açısından Yıldız Sineması'nın eski gişe memurlarına da kulak verilebilir:

Film değiştiği günlerde sabah sekizde dokuzda sinemanın kapısı dolu olurdu. Telefonla da yer ayırtırlardı. Doluydu, her seans doluydu (Ülfet Işıkalp, 74).

Abone müşterilerimiz vardı. Yer ayırtırlardı. Gelseler de gelmeseler de onlara ayrılırdı. Ayakta da alınırdı. Ayakta yer istiyorum diye gelenler vardı. Öyle bir bilet yok hâlbuki. Sinemaya o kadar tutkunluk vardı [...] İnsanlar gişeye öyle bir yüklenirdi ki biz gişenin çıtırtısını duyardık. Koçan bilet sattığımızı biliriz. Koçan 100 kişiliktir (Nadide Özdemir, 63).

Ellili yılların sonu itibariyle, sinemaların sınıfına ve oturma yerlerine bağlı olarak, 100 ila 200 kuruş arası bir bilet ücretiyle (dolmuş üc-

6 Ali Ulvi, ellili ylllardan itibaren İzmir'in popüler bir aile çay bahçesidir. Mekânda Müzeyyen Senar ve Safiye Ayla da dâhil olmak üzere, yerli ses sanatkârlarının konserler verdikleri bilinmektedir (Dağtaş, 2004).

7 Geceleri Sokağa Çıkabiliyor musunuz? (1962, 13 Aralık). Yeni Asır, 3.

8 Sinemada İken Evi Soyuldu (1962, 28 Ağustos). Yeni Asır, 7; Bir Aile, Tam 3000 Liraya Film Seyretti (1964, 4 Haziran). Yeni Asır, 3; Sinemada İken Eve Hirsiz Girdi (1965, 25 Mart). Yeni Assr, 3. 
reti 40-50 kuruş) sinemalara girilebilmektedir. ${ }^{9}$ Loca fiyatları ise 5-10 lira arasında değişmektedir. ${ }^{10}$ Bilet fiyatları ucuz gibi görünse ve sinemacılar sürekli belediyeden zam istese de, altmışlı yıllar boyunca halkın, artan hayat pahalılığını ve sinemanın tek eğlenceleri oluşunu ileri sürerek, sinemaya yapılacak zamları onaylamadığı ve sinemanın ucuzluğunun onu popüler kılan belki de en önemli neden olduğu görülür. ${ }^{11}$ 1970'te dönemin belediye başkanı Osman Kibar'ın sinemacıların zam isteklerine şu sözlerle cevap verdiği rapor edilmiştir: "Fakir İzmir'in tek eğlence yeri sinemadır. Zam talebi karşısında direteceğiz." ${ }^{12}$ Sinema biletleri üzerinden alınan "Belediye rüsumu" adlı eğlence vergisinin altmışlı yıllarda belediyenin gelirleri arasında en yüksek bölümü teşkil etmesi, sinemanın popülerliğini ve düşük bilet ücretlerine rağmen edinilen geliri göstermesi açısından önemlidir. ${ }^{13}$

İzmir'de yaz aylarında faaliyette bulunan açık hava sinemaları, kentteki sinema ortamının bir başka boyutunu temsil eder. Genelde mahalle aralarında yer alan ve sadece film izlemeye değil, sıcak yaz gecelerinde serinlemeye de gidilen, bazen bilet ücretleri 30 kuruşa kadar düşen bu sinemalar, gerek gençler gerekse aileler arasında oldukça popülerdir. Üstelik kapalı sinemalara gündüz altı, gece on iki yaşın altında çocuklar alınmazken; açık hava sinemalarına bebekler bile kabul edilir. ${ }^{14}$ 1966'da, İzmir Belediyesi sınırları içinde açık hava sinemalarına bir hafta içerisinde yaklaşık 500,000 kişinin gittiği, üstelik bu rakama Buca, Bornova, Yeşilyurt, Gültepe, Balçova, Çamdibi gibi yerlerin de dâhil olmadığı tespit edilmiştir. ${ }^{15}$

\section{Sinema Salonları}

1951 İzmir Şehri İmar Komisyonun Raporu'na göre, ellili yılların başında yedisi İzmir ve beşi yakın yerleşim yerlerinde (Karşıyaka, Bornova, Buca) olmak üzere toplam 12 kapalı sinema salonu bulunmaktadır (Göl-

\footnotetext{
9 Sinema Ücretleri Yükseldi (1959, 19 Şubat). Yeni Asır, 2.

${ }^{10}$ Sinema Ücretlerine Yeniden Zam Yapıldı (1959, 19 Temmuz), 2.

${ }^{11}$ Sinemaya Zam Yapılmalı mı? (1964, 20 Şubat). Yeni Asır, 3; İzmirliler Sinemaya Yapılacak Zama "Hayır" Dedi (1969, 22 Ekim). Yeni Asır, 3.

12 İzmir'de Sinemaya Şimdilik Zam Yok (1970, 21 Kasım), Yeni Asır, 2.

13 (1966, Aralık). Beyaz Perde Haberleri, 3, 2; (1968, Mayıs). Beyaz Perde Haberleri, 8, 1.

${ }^{14}$ Küçük Çocuk Almak İsteyen Sinemacıların Teklifi Reddedildi (1964, 12 Aralık). Yeni Asır, 3.

${ }^{15} 500$ Bin Kişi Açıkhava Sinemasına Gidiyor (1966, 23 Temmuz). Yeni Asır, 3.
} 
gesiz Gedikler, 2006, s. 528). 1958 itibariyle bu sayının sadece İzmir'de bir düzineyi aştığı görülür. Bu sinemalar şunlardır: Elhamra (Konak), Tayyare (Alsancak), Ylldız (Basmane), İkbal (Basmane), Kulüp (Basmane), Büyük (Basmane), Yeni (Mezarlıkbaşı), Lale (Mezarlıkpaşı), İnci (Mezarlıkbaşı), Saray (Mezarlıkbaşı), Tan (Mezarlıkbaşı), Şenocak (Eşrefpaşa), Konak (Kemeraltı), Köşk (Küçükyalı). ${ }^{16}$ Altmışların ortasında İzmir'de kapalı sinemaların sayısı 40'ı, yetmişlere doğruysa $60^{\prime}$ ' geçer. ${ }^{17}$

Elhamra Sineması, hizmete girdiği 1926 yılından Kültür Bakanlığı tarafindan restore edilerek Opera Sahnesi'ne çevrildiği

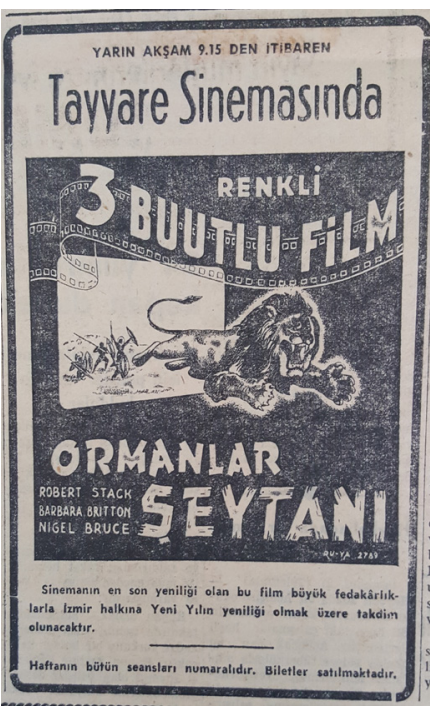
1979 yılına dek, "İzmir'in en seçkin sinema salonu" olarak bilinir (Makal, 1999, s. 107), ki bu durum bu çalışma kapsamında yapılan görüşmelerde de sıkça dile getirilmiştir. 840 koltuk kapasitesine sahip bina, "oryantal stilde, Doğu atmosferini veren kandiller ile donatılmıştır. Bina içinde yer yer çini panolara rastlanır. Ayrıca balkonun altını oluşturan tavan tamamıyla Türk nakışları ile bezenmiştir" (Makal, 1999, s. 108). Kökü 1908'e giden eski bir İzmir sinemasinın (Cine Pallas) 1926 yllında Tayyare Cemiyeti tarafından satın alınıp, 1933-1934 yılları arasında modern tarzda restore edilmesiyle ortaya çıkan Tayyare Sineması ise, yedi loca, bir salon ve iki balkonuyla toplamda 370-380 kişilik bir sinemadır. Diğer sinemalara kıyasla küçük bir sinema olsa da Tayyare, gelişmiş ses ve klima sistemleriyle, yıkılıp apartmana çevrildiği 1968 yılına dek Kordon'un diğer bir seçkin sineması olarak hizmet verir (Makal, 1999, s. 212; Kaya, 2016, 68). Görüşmelerde, Elhamra Sineması'nın yanı sıra Tayyare Sineması'nın da ayrıcalıklı olarak hatırlandığı görülmüştür. Her iki sinemanın da, diğer sinemalardan farklı olarak, genelde altyazıll, tek film ve birinci vizyon yabancı filmler göstermesi ayrıcalıklı konumlarının bir ifadesi olarak okunabilir. Bununla birlikte, yapılan gazete taramasında Tayyare Sineması'nın ellilerde yerli filmlere de programında yer verdiği görülmüştür. ${ }^{18}$

\footnotetext{
16 (1958, Ekim). Beyaz Perde Haberleri, 1, 4.

${ }_{17}$ (1966, Kasım). Beyaz Perde Haberleri 2, 2; (1968, Mayıs), Beyaz Perde Haberleri, 8, 1.

18 Örneğin Kubilay (Muharrem Gürses, 1953), Süt Kuzularn (Vahi Öz, 1953), Yıldırım Beyazıt
} 
Elhamra ve Tayyare sinemaları, teknolojik yenilikleri takip etmekte de diğer sinemalardan önde gözükmektedirler. 1953'ten başlayarak Tayyare Sineması'nda üç boyutlu birkaç filmin gösterildiği saptanmıştır. Örneğin dünyada üç boyutlu film çılgınlığını başlatan film olarak bilinen Amerikan yapımı Bwana Devil (Arch Oboler, 1952), 29 Aralık 1953 akşamı Tayyare Sineması'nda Ormanlar Şeytanı adıyla gösterime girmiştir. ${ }^{19} 1954$ 'te Tayyare'de gösterilen bir başka üç boyutlu film de Canavarlar Sarayı'dır (House of Wax, André De Toth, 1953). Panoramik ekran uygulamasinın da 1954 yllında Elhamra ve Yeni Sinemalarında kullanılmaya başlandığı görülür. ${ }^{20} 1955^{\prime}$ te Elhamra, ayrıca, İzmir'e sinemaskop teknolojisini getirmekle övünmektedir. ${ }^{21}$

Diğer sinemalar arasında Lale, Yeni, İnci, Saray ve Tan sinemaları, Mezarlıkbaşı'nda konuşlanmış "tevazu sahibi" sinemalardır (Ürük, 2013d, s. 64-65). Ürük, bu sinemaların bölgedeki egemenliğinin ellili yıllarda Basmane-Tepecik ekseninde birbiri ardına açılan Yıldız, İkbal, Kulüp ve Büyük sinemalarıyla sona erdiğini kaydeder (2013d, s. 65). 1951 yılında açılan Büyük Sinema, 2180 koltuk kapasitesiyle sadece Basmane bölgesinin değil, İzmir'in en büyük kapalı sinemasıdır (Gölgesiz Gedikler, 2006, s. 530). Gazetelerdeki film ilanlarından sinemanın yerli film gösterimlerinin yanı sıra yerli sanatçıların konserlerine de ev sahipliği yaptığı anlaşılmaktadır.

Basmane'nin bir diğer sineması olan 1800 koltuk kapasiteli Yıldız Sineması ise, daha önce aynı yerde bulunan yazlık Güneş Sineması'nın 1953 yılında kapalıya çevrilmesiyle ortaya çıkmıştır. ${ }^{22}$ Bir İtalyan mimar tarafından tasarlanan ve Oğuz Makal'ın "Türkiye'de eşi olmayan bir sinema" (1999, s. 232) olarak nitelediği sinemanın tavanında havalandırma amaçlı açılır-kapanır kapaklar bulunaktadır. Sinemanın adının da geceleri bu kapakların açılmasıyla görülebilecek yıldızlardan geldiği söylenir (Makal, 1999, s. 233; Ürük, 2013b, s. 56-57). ̇̇lk açılışında Yıldız Sineması ve Tiyatrosu olarak lanse edilen yapının açılır-kapanır

ve Timurlenk (Münir Hayri Egeli, 1953), Salgın (Ali M. İpar, 1954), Aşk Izdıraptır (Atıf Yılmaz, 1954).

19 (1953, 28 Aralık). Yeni Asır, 4.

${ }^{20}$ Panaromik Ekran (1954, 23 Arallk). Yeni Asır, 2.

${ }^{21}$ (1955, 8 Mart). Yeni Asır, 6.

${ }^{22}$ Bu bölümde Yıldız Sineması ile ilgili verdiğimiz bilgiler, aksi belirtilmedikçe, sahibi Yüksel Kazmirci ile 15 Mart 2016 tarihinde yaptığımız görüşmeden alınmıştır. Ayrıca bkz. Makal (1999); Ürük (2013a, 2013b, 2013c, 2013d); Beşikci (2015); Akçura, (2016). 


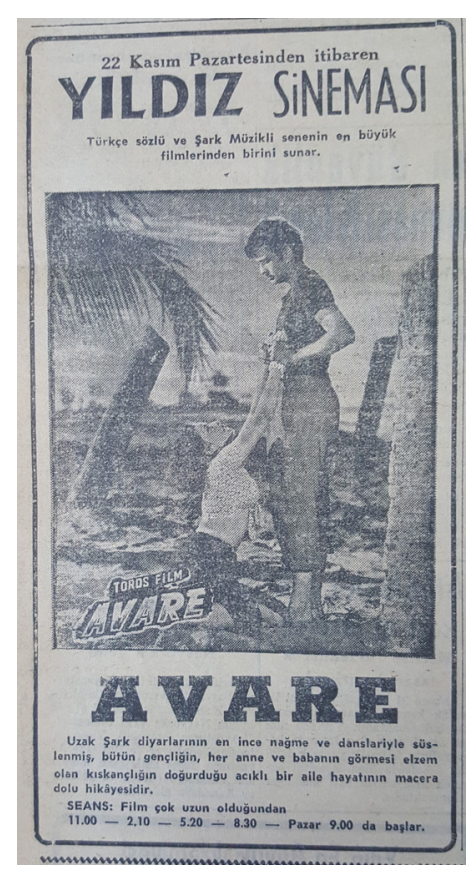

tavan kapaklarına gazetelere verilen ilanlarda da vurgu yapıldığı görülür. İlanlarda şu tanitım bilgisi yer alır: "Net ses, mükemmel projeksiyon, rahat koltuk, geniş salonlar ve en güzel filmler. Raylar üzerine oturan çatı otomatik surette açılarak yazlık sinemaya inkılap ettiği gibi, havasinı daima temiz tutar." ${ }^{\prime 23}$ Haziran 1953'te açılan sinema, yıkılıp yeniden yapılacağı 1957 yllına dek, başta birinci vizyon dublaj Amerikan filmleri ve takiben kıta Avrupası (İtalyan, Alman, Fransız) filmleri olmak üzere, yerli sinema örneklerine ve yaz aylarında İstanbul Belediyesi Şehir Tiyatrosu Komedi Kismi temsillerine programinda yer verir. 1955 yllında, Fransız Moulin Rouge Revüsü'nün de Ylldız Sineması'nda gösteriler yaptığ 1 tespit edilmiştir. ${ }^{24} \mathrm{Si}$ nemanin bu ilk dönemindeki en önemli sinema olayı ise 1954'te gösterime sokulan ve tahmin edilenin çok ötesinde ilgiyle karşılanan Avare (Awara, Raj Kapoor, 1951) filmidir. Yüksel Kazmirci (85), filmi Toros Film'in sahibi Toros Şenel'in önerisiyle, pek de emin olmadan gösterime soktuklarını belirtir. Kazmirci'nin yaşadığı tereddüdün sinemanın arşivlerinde bulunan el yazısı ile düzenlenmiş 8 Aralık 1953 tarihli anlaşmaya da yansıdığı görülür. Anlaşmada Toros Film, Yıldız Sineması'nın kârdan alacağı \%60 payın 5000 liradan aşağı olması halinde aradaki farkı ödemeyi taahhüt eder. Anlaşmada gösterim tarihi olarak her ne kadar 3-9 Ocak aralığı belirtilse de, yapılan gazete taramasından filmin ancak 22 Kasım 1954'te gösterime girebildiği ve o zamanki tüm filmler gibi bir hafta oynadığı tespit edilmiştir. ${ }^{25} \mathrm{Bu}$ tarih, Avare'nin ilk defa ve İstanbul'dan da önce İzmir'de gösterildiğini kanıtlar. ${ }^{26}$ Kazmirci, film sahibinin yurt dışında olması nedeniyle Avare'nin gösterimini isteseler de uzatamadıklarını belirtir. Film tekrar 3 Ocak 1955'te gösterime sokulur ve bu sefer iki hafta gösterimde kalır.

\footnotetext{
${ }^{23}$ (1953, 6 Haziran). Yeni Asır, 6; (1953, 8 Haziran). Yeni Asır, 4; (1953, 10 Haziran). Yeni Asır, 6. ${ }^{24}$ (1955, 25 Ekim). Yeni Asur, 6.

25 (1954, 22 Kasım). Yeni Asır, 4.

${ }^{26}$ Avare'nin İstanbul'da ilk gösterim tarihi 15 Şubat 1955 olarak belirtilmektedir (Gürata, 2010, s. 69).
} 
Filmin "son gün" ilanında 150.000 kişi tarafından izlendiği belirtilmektedir. ${ }^{27} \mathrm{O}$ dönemin standartlarına göre Avare'nin toplamda üç hafta aynı sinemada gösterilmesi bir rekordur, zira filmler genelde bir haftadan sonra gösterimden çekilir. Kazmirci, Avare'nin üç saatin üzerinde olmasına rağmen kısaltılmadan gösterildiğini, bu yüzden sadece Avare ile (normalde iki film) günde dört seans yaptıklarını ve buna rağmen büyük gelir sağladıklarını ifade etmiştir. Filmin gördüğü ilgiden kaynaklı olsa gerek, takip eden zamanlarda başka Hint filmlerinin de sadece Ylldız'da değil diğer sinemalarda da gösterildiği gazete ilanlarından anlaşılmaktadır. ${ }^{28}$

Yıldız Sineması 1957'de perdeye yakın iki kolonun görüşü engellemesi nedeniyle yıkılıp Mimar Erdoğan Tözge'nin tasarımıyla yeniden inşa edilir. Bu yeni tasarımda da tavanda açlır-kapanır havalandırma kapaklar mevcutsa da, altlarındaki asma tavan nedeniyle artık izleyiciler tarafından görülemezler. Yeni bina 22 Mart 1957 gecesi, İzmir Basın Mensupları Dayanışma Derneği'nin düzenlediği Zeki Müren konseriyle açılır ${ }^{29}$ ve yetmişlerin ilk yıllarına dek ağırlıklı olarak birinci vizyon yabancı dublaj filmler (ara sıra yerli filmlere de yer vererek) göstermeye devam eder.

1969'da Yeni Asır gazetesinin "İzmir'de Bugün Bu Gece" köşesinde listelenen toplam 11 mekân arasında yer alan iki sinemadan birisi Yıldız Sineması'dır. ${ }^{30}$ O yıllarda İzmir'de altmışın üzerinde kapalı sinema salonunun olduğu düşünülecek olursa, listeye seçilen iki sinemadan birisinin Yıldız Sineması oluşu sinemanın bu yıllardaki popülerliği hakkında da fikir verir. Yapmış olduğumuz sözlü tarih görüşmelerinde ise Ylldız Sineması'ndan genelde büyük, bakımlı ve nezih bir sinema olarak bahsedilmiştir. Altmışlı ve yetmişli yıllarda Basmane'deki sinemalara, özellikle "üst düzey" şeklinde nitelediği Yıldız Sineması'na sıklıkla gittiğini belirten Mustafa Çalışık (65), Yıldız'ın diğer sinemalardan farkını temiz havasına vurgu yaparak açıklamıştır:

Hizmeti çok güzeldi. Mesela o sinemaya girdiğim zaman o kokusu bana başka gelirdi yani. Bakılıyordu o sinemaya yani. Sadece girip oturmak falan değil. Teşvik edici bir şeyi de vardı. Nasıl yapıyorlardı o kokuyu

\footnotetext{
${ }^{27}$ (1954, 19 Aralık). Yeni Asır, 6; (1955, 6 Ocak). Yeni Asır, 6; (1955, 9 Ocak). Yeni Asır, 6; (1955, 16 Ocak). Yeni Asır, 6.

${ }^{28}$ Türkiye'de Hint filmlerinin bir incelemesi için bkz. Gürata (2010).

${ }^{29}$ (1957, 22 Mart). Yeni Asır, 4.

30 İzmir'de Bugün Bu Gece (1969, 4 Ocak). Yeni Asır, 4.
} 
bilemiyorum ama ayrı bir kokusu vardı. Mazot kokusuyla parfüm kokusu arası bir şeydi... Tahtaydı yerleri. Galiba bir mazotla onu siliyorlardı. Ondan sonra da üzerine başka bir şey geçiyorlardı. O hava vardı. Bir temizlik havası alıyordunuz. Ötekilere girdiğim zaman bir nefes kokusu geliyordu bana.

1953'te Anadolu yerel gazetesinde bir haberden, belediyenin bulaşıcı hastalıkları önlemek amacıyla sinemalara "sürekli olarak mazotlanması ve seans aralarında havalandırılarak salona kolonya dökülmesi" şartını getirdiği anlaşılmaktadır (Gölgesiz Gedikler, 2006, s. 531). Ylldız Sineması'nın son baş makinisti Rüstem Çetin (82) ise, kendisiyle binayı gezdiğimizde, salon duvarının yerle birleştiği bir köşedeki kapağı açarak arkasının talaş deposu olduğunu belirtmiş ve sinemaya güzel koku vermek için yerleri çam talaşıyla sildiklerini ifade etmiştir. Ayrıca, makine dairesinden salona filit pompasıyla parfüm sıktıklarını, bazen mikropları kırmak amacıyla ilaç da kullandıklarını açıklamıştır. Bu açıklamalar, Çalışık'ın hafızasındaki koku algısıyla tutarlılık gösterir. Sinemanın temiz havasına tavandaki havalandırma kapaklarının da etkisi olmuş olmalıdır.

Ellili yıllardan itibaren İzmir'de yazlık açık hava sinemaları da artar. Belediye Encümeni'nin kararıyla I Mayıs'ta açılıp I Kasım'a kadar devam eden ${ }^{31}$ bu sinemaların sayısı 1954'te 20 civarındayken (Gölgesiz Gedikler, 2006, s. 533), bu sayının 1958'de 63, ${ }^{32} 1963^{\prime}$ te $77^{33} 1970$ 'de $85^{\prime}$ e kadar çıktığı görülür. ${ }^{34} 1960$ yılında açılan 5,000 kişilik Büyük Şenocak Açıkhava Sineması, bu sinemaların en büyüğü olup 17 metre uzunluğunda bir perdeye sahiptir. Sinema içerisinde ayrıca ziyaretçilerin yemeklerini de getirebilecekleri bir çay bahçesi bulunmaktadır. Ziyaretçiler, 75 kuruş ücret karşılığında sadece film seyretmekle kalmayıp "kukla, atraksiyon, alaturka saz ve şarkılar" gibi eğlenceleri de tadabilmektedir. ${ }^{35}$ Aynı dönemde, Tepecik ve Gürçeşme mevkilerinde de 2000 ila 5000 arasında seyirci kapasitesine sahip açık hava sinemalarının olduğu ve rekabet dolayısıyla programlarına filmlerin yanı sıra kukla ve konserler, skeç ve sürprizler ekleyip bilet ücretini 30 kuruşa kadar düşürdükleri belirtilmiştir. ${ }^{36} \mathrm{Bu}$ bağlamda, çalışma kapsaminda

\footnotetext{
${ }^{31}$ Açıkhava Sinemaları Yarın Akşam Kapanıyor (1960, 8 Kasım). Yeni Asır, 2.

${ }^{32}$ Yazlık Sinema Hazırlıkları (1958, 18 Nisan). Yeni Asır, 2.

${ }^{33}$ Açıkhava Sinemaları Açılıyor (1963, 2 Nisan). Yeni Asır, 2.

${ }^{34}$ İzmir'de Yazlık Sinemalar 1 Mayıs Günü Açıllyor (1970, 29 Nisan). Yeni Asır, 1.

${ }^{35}$ Açıkhava Sinemalarının En Büyüğü Açıllyor (1960, 14 Mayıs). Yeni Asır, 2.

${ }^{36}$ Açıkhava Sinemaları Arasında Rekabet (1960, 21 Mayıs). Yeni Asır, 2.
} 
görüştüğümüz kişilerden açık hava sinemalarında çekiliş yapıldığını ve kemençe, yorgan gibi hediyeler kazandığını belirtenler de olmuştur (Tanzer Başer Ökte, 65; Çimen Kanıer, 72). Açık hava sinemalarının Eylül ayından itibaren havaların serinlemesiyle düşen seyirci ilgisini geri çekmek için film kalitesini artırmak ve/veya filmlerde oynayan sanatçıları İzmir'e getirerek film aralarında seyirciye sunmak gibi yöntemlere başvurduğu da görülmektedir. ${ }^{37}$

İzmir'in sinema ortamına bu kısa ve genel bakıştan sonra, makalenin geri kalan kısmında, çalışma kapsamında yapmış olduğumuz görüşmelere odaklanıyor ve kentte sinemanın sosyal deneyimini inceliyoruz.

\section{Bir Olay Olarak Sinemaya Gitme}

Sözlü tarih görüşmesi yapılan erkek katılımcılardan bazıları, sinemaya hiçbir plan yapmadan, örneğin kahvede arkadaşlarla konuşurken veya bir sinemanın önünden geçerken birden bire karar vererek gittiklerini söylerken, diğerleri (erkekler de olmakla birlikte çokluk kadınlar), özellikle çocuklukta ve gençlik öncesi yıllarda, sinemaya gitmenin başlı başına anlamlı bir olay olduğunu ifade etmişlerdir. Bazen hangi filme gidileceği günlerce önceden planlanır, sabırsızlıkla beklenir ve heyecanla gidilir. Çok özel olmasa bile düzgün kıyafetler giyilir. Kadınlar bazen hafif bir makyajla birlikte saçını yapar. Örneğin Ali Ulvi Tunalı (65) sinemaya gitmenin çocukluğunda nasıl bir olay olduğunu şu sözlerle anlatır:

Çocukluğumuzda sinema hazırlanılıp ziyarete gidilen, bir büyüğümüz gibi, öyle bir şeydi. Ailemizle sinemaya gideceğimiz zaman bu bir hafta içinde planlanır, işte bu Cumartesi veya Pazar şu seansa sinemaya gideceğiz diye bir telaş olurdu. Bir aktiviteydi bizim için, sosyal bir şeydi.

Çarşamba günleri okulun yarım gün olduğunu söyleyen Tunalı, arkadaşlarıyla sinemaya gitmek için Çarşamba öğleden sonralarını "büyük bir heyecanla" beklediklerini de ekler. Figen Saygın (60) ise genç bir kız olmaya başladığı dönemlerde sinemaya gidecek olmanın verdiği heyecanı şu sözlerle anlatır:

Sinemaya gideceğimizi öğrendiğimiz zamanlar o anki mutluluğu anlatamam yani. Yemek bile yemezdik. Eteklerimiz zil çalardı. Bir hazırlık bir hazırlık. Annemin diktiği elbiseleri giymek, ben yeni yetişiyorum,

${ }^{37}$ Açıkhava Sinemalarına İlgi Azaldı (1965, 25 Eylül). Yeni Asır، 3. 
ipek naylon çorap giymek. Muhakkak saçını başını toplamak. Babadan izinli olarak hafif bir makyaj yapmak.

Genelde gittikleri sinemanın evlerine yakın olduğunu söyleyen Saygın, nereye gidildiğinden ve ne kadar yolculuk yapıldığından bağımsız olarak, sinemaya gitme olayının başlı başına büyülü bir yolculuk olduğunu da şu sözlerle ifade eder:

Sinema evimizin iki arka sokağındaydı ama sanki biz vasıtalara binip çok büyük ve çok uzak bir yerlere gidiyormuşuz hissi uyandırırdı bizde... Ya bizim dünyamız çok küçücüktü, etrafı çok geniş görüyorduk. Ben yıllar sonra büyük bir heyecanla o sinemanın sokaklarına girdiğim zaman oranın bir çarşıdan daha dar bir mahalle olduğunu gördüm ve çok şaşırdım. Biz buraya mı bu kadar büyük bir heyecanla, büyük bir hazırlıkla geliyorduk?

"Çok büyük bir heyecandı. Biz çocuklar daha gündüzden akşam sinemaya gideceğiz diye kafamızda hazırlardık," diyerek söze başlayan bir başka kadın görüşmeci Tanzer Başer Ökte (65) ise kendisi için çayın tadından çok onun ritüelinin önemli olduğunu belirterek "sinema da öyleydi" der. Ali Ulvi Tunalı (65), sinema mekânının da öneminin altını çizerek, filmin başlayışındaki ritüelistik havadan etkilendiğini şu sözlerle ifade eder: "Yüksek tavanlı. İhtişamlı, mabet gibi. Aydınlatmalar, perde... Filmler huşu içinde izlenirdi. Bir kadife perdesi olurdu genelde. Ağır ağır açılır. Herkes kendine çeki düzen verir falan. Sonra gong çalar. Öyle bir ritüelle başlar". Bazı sinema mekânlarının, sadece ihtişamlı iç mekânlarıyla değil, koltuklarının gıcırtısı veya tahta kokusu gibi görme dışında duyuları harekete geçiren özellikleriyle de seyircilere ayrı bir sinemada olma hazzı verdiği görülür. Örneğin, Elhamra Sineması'nın "ayrı bir ekol" olduğunu söyleyen Tanzer Başer Ökte (65), şu sözlerle devam eder: "Elhamra'ya girince o koltukların gıcırtısı insana bir sükûnet verirdi. O loş havası, yüksek tavanı. Freskler vardı. Keşke hep sinema olarak kalsaydı." Figen Saygın (60) da Hatay Sineması'na gönderme yaparak şu açıklamada bulunur: "orada içeriye girerken böyle tahtaların eski olmasının verdiği koku... Sinemaya girdiğinizi anlardınız o kokudan."

Tanzer Başer Ökte (65) sadece sinemaya gitme, sinemada bulunma durumunun değil sinemada film seyretme eyleminin de önemli olduğunu hatırlatır: "Sinemaya gitmek, sinemaya gitmiş olmak, sinemada bulunmak, o filmi görmek, hazmetmek çok önemliydi. Önceden filmin şanını duyardık yani. Filanca film gelmiş." 18 yaşında genç bir anneyken, kendi deyimiyle "cahillikten" bir yaşındaki oğlunun üzeri- 
ne kapıyı kilitleyerek ev sahibiyle ve onun kızıyla sinemaya gittiklerini söyleyen bir başka kadın görüşmeci Gülperi İzci (81) de o ylllarda sinemada film izleme tutkusunu şu sözlerle ifade eder: "Sinemada gelecek filmlerin reklamını görünce o haftayı zor yapardık. Çamaşır yıkasak, iş yapsak da film aklımızdan çıkmazdı."

\section{Bir Mücadele Olarak Sinemaya Gitme}

Geçmişin sinemaları düşük bir ücret karşılığında her kesimden her insanın rahatça girebildiği kamu alanları olarak algılanagelmiştir. Bununla birlikte, 1950-1980 arasında Türkiye'deki sinema mekânlarını sözlü tarih aracılığıyla inceleyen Serdar Öztürk'ün de saptadığı gibi, sinemaya gitmek emek isteyen bir edimdir (2013, s. 22). Örneğin sinemaya ulaşabilmek bir emek ister. İzmir bağlamında yapılan bu çalışmanın sözlü tarih kısmında da bu durum gözlemlenmiştir. Sinemaya mesafenin uzaklığı, ulaşım eksikliği veya ulaşımın ekstra maliyeti sebebiyle, pek çok görüşmecinin, genelde muhitlerindeki sinemaya gitmeyi tercih ettikleri görülmüştür. Bununla birlikte, çok görülmek istenen bir film olduğunda veya cumartesi akşamları özel bir sinemada film seyretmek için yakın olmasa da, belirli bir sinemaya gidenler de vardır. Görüşmecilerden Leyla Eskicioğlu'nun (65) aşağıdaki sözleri, sinemaya ulaşmak kadar filme yetişmenin de bazen emek ve fedakârlık istediğini anlatır niteliktedir:

O zaman muhitimizdeki sinemaları bitirir, Basmane'de bir sinema vardı oraya bilet almıştı eşim. Geç kalmayalım, otobüse yetişelim diye koşturuyoruz. Ben de yeni evliyim ya yüksek topuklu ayakkabılar var ayağımda. Benim topuğum kırıldı. Şimdiki aklım olsa eve dönerim ayakkabımı değiştiririm. Filmin başını kaçırmayalım diye ben bir elimde topuk, biri düz diğeri topuklu topal topal öyle gittim sinemaya.

Sinemaya gitmenin gerektirdiği emek, bilet alacak parayı bulabilmek, uzun kuyruklarda beklemek, istenilen filme bilet bulabilmek, biletsiz girebilme yollarını aramak, hatta özellikle çocuklar ve öğrenciler açısından, sinemaya girebilmek gibi pek çok başka şekilde de olabilir. Aslında sinemaların herkesin rahatlıkla ve kolayca gidebildiği kamu mekânları olduğu düşüncesi tam olarak doğru değildir. Örneğin Yeni Asır'da bilet parasını bulabilmek için hırsızlığa teşebbüs eden çocuk haberleri görülür..$^{38}$ Ekonomik kısıtlllıkların yanı sıra, öğrencilerin sine-

${ }^{38}$ Sinema Parası İçin Hırsızlık Yapan 4 Çocuk Yakalandı (1962, 1 Aralık). Yeni Asır, 8; Sinemaya Gitmek İçin Annesinin Mücevherlerini Çaldı (1964, 15 Ocak). Yeni Asır, 2. 
malara katılımı üzerinde resmi sınırlamalar da vardır. Altmışlı yıllarda öğrencilerin ders saatinde sinemalara kabul edilmesinin yasak olduğu ve sinemaların bu konuda polis tarafından denetlendiği görülür. ${ }^{39}$ 11 Ocak 1960 tarihli bir gazete haberi, yapılan kontrollerde son sekiz gün içinde gündüz seanslarında toplam 81 öğrencinin tespit edilerek okullarına ve velilerine bildirildiğini rapor etmektedir..$^{\circ}$ Bununla birlikte, bu tür yaptırımların öğrencileri gündüzleri sinemalardan uzak tutmaya yetmediği görülür. 1970'te Yeni Asır'da yayınlanan bir okur görüşünde, bir baba, özellikle gösterimdeki filmin değiştiği günlerde okul vaktinde sinema önlerinin "okulu asan" öğrencilerle dolu olduğunu belirtmekte ve velileri uyarmaktadır. ${ }^{41}$ Yaptığımız görüşmelerden birinde "okuldan kaçıp sinemaya gitmek idealimizdi" diyen bir erkek görüşmeci, bu eylemin sadece emek değil mücadele içerdiğini şu sözlerle anlatır: "Çantaları fuara saklarız, çalıların içine, kimse de almaz oradan. Gelirdik hangi sinemada güzel film var bakardık ederdik. Okul önlüklerini saklardık, çantaya koyardık. Formalı öğrenci gündüz vakitleri almazlardı. Ortaokulda kep giyerdik, kepleri saklardık" (Şükrü Yılmaz, 70). Okuldan kaçıp sinemada öğretmene yakalanma hikâyeleri de bazı erkek görüşmecilerin anlattıkları anekdotlar arasındadır. $\mathrm{Bu}$ sebeple olsa gerekir ki bir görüşmeci, okuldan kaçıp sinemaya gittiklerinde, kendi muhitlerindekileri değil, başka muhitlerdeki sinemaları seçtiklerini söylemiştir (İhsan Helvacı, 70).

Altmışlı yıllarda öğrenciler gibi çocuklar için de yasal kısıtlamalar bulunmaktadır. Kapalı sinemalara gündüz altı, gece on iki yaşın altındaki çocukların kabul edilmesi yasaktır. ${ }^{42} 1964$ 'te, sinema sahiplerinin yasağın kaldırılması için belediyeye başvursa da sonuç alamadıkları ve yasağın devam ettiği görülür..$^{43}$ Çocuklar üzerindeki yaş kısıtlamasının çocuklu aileleri ve kadınları da etkilediği ve ara sıra sinemaların ceza

${ }^{39}$ Ders Saatinde Öğrenci Alan Sinemalar Kapatılabilecek (1960, 11 Ocak). Yeni Asır, 2; Sinemaya Kaçıyorlar (1960, 20 Aralık). Yeni Asır, 2; Talebeler Gündüz Sinemaya Gidemeyecek (1960, 21 Aralık). Yeni Asur, 2.

${ }^{40}$ Ders Saatinde Öğrenci Alan Sinemalar Kapatılabilecek (1960, 11 Ocak). Yeni Asır, 2.

${ }^{41}$ Çocuğunu Okulda Sananlar Sinema Önlerine Bir Baksınlar (1970, 31 Ekim). Yeni Asır, 6.

${ }^{42}$ Bununla birlikte, bazı sinemalarda çocuklara özel matinelerin veya film gösterimlerinin varlığından bahsetmek mümkündür. Örneğin bkz. Kültür Filmleri Yalnız Çocuk Seanslarında Gösterilecek (1958, 14 Mart), Yeni Asır, 2; İzmir'de Bir Çocuk Sineması Kuruldu (1965, 6 Kasım). Yeni Asır, 3.

${ }^{43}$ Küçük Çocuk Almak İsteyen Sinemacıların Teklifi Reddedildi (1964, 12 Aralık). Yeni Asır, 3. 
almasına da sebep olacak kaçak taktikler geliştirmeye sevk ettiği görülür. ${ }^{44}$ 1969'da Yeni Asır gazetesinde yayınlanan "Karşıyaka, çocuklu ailelerden bir grup" imzalı bir mektupta, "Karşıyakalı anneler," sinemaların altı yaşından küçük çocuk kabul etmemelerini kendileri için "oldukça mühim bir sıkıntı" olarak tarif etmekte ve durumu aşağıdaki şekilde açlklamaktadırlar:

Karşıyaka'nın başka hiçbir yere benzemeyen bir özelliği vardır. Burada herkes bir aile efradı gibidir. Sokakta, çarşıda evindeki gibi rahattır ve rahatsız edilmez. Ev kadınları boş zamanlarını çeşitli şekillerde değerlendirdikleri gibi, arada bir sinemaya da giderler. Fakat ne var ki, sinemalar 6 yaşından aşağı çocukları kabul etmez. Böyle olunca ana ve babanın da sinemadan mahrum edilmesi sonucu ortaya çıkıyor. Herkes sinemaya gidebilmek için dar tutamaz ya. ${ }^{45}$

Yukarıdaki mektupta, söze Karşıyaka'da kadınların rahatsız edilme korkusu yaşamadan dışarıya çıkabildiklerine ve sinemaya da gittiklerine vurgu yapılarak başlanması, o dönemlerde, sadece sinemaya gitmenin değil rahatça sokağa çıkıp dolaşabilmenin bile kadınlar için ayrıca bir mesele olduğunun altını çizer.

\section{Kolektif Bir Eylem Olarak Sinemaya Gitme ve Kadınlar}

Ellili ylllardan yetmişlerin ortasına dek, sinemaya gitmek, çoğu zaman arkadaşlarla, aile üyeleriyle veya komşularla birlikte yapılan kolektif bir eylemdir. Bu eylem, gerek popüler kültürde gerekse ilgili akademik çalışmalarda, genelde samimi ve şenlikli bir tecrübe olarak tarif edile gelmişse de İzmir bağlamında yapılan bu çalışmada elde edilen veriler, bu tarifin erkekler için çok daha geçerli olup kadınlar için, yanlış olmasa bile, eksik bir tarif olduğunu düşündürmektedir.

Miriam Hansen, Amerika'da sinemanin erken dönemlerinde sinema salonlarının kadınlar için "alternatif" bir kamusal alan işlevi gördüğünü vurgular. Hansen'e göre, bu mekânlarda kadınlar, toplumda kendilerine pek de yakıştırılmayan, hatta izin verilmeyen, bakma ve "gözetleme (voyeurizm)" deneyimini özgürce yaşarlar (aktaran Mayne, 1993: 67). Bu tespit elbette sadece Amerika ile sınırlı değildir. Başka coğrafyalarda ve kültürlerde de sinemanın, özellikle sinemaya gitmenin başat bir eğlence biçimi olmaya başladığı dönemlerde, böyle bir iş-

\footnotetext{
${ }^{44}$ Sinemacılar Dertli Oldu (1965, 4 Ocak). Yeni Asır, 4.

${ }^{45}$ Çocukları Sinemaya Sokulmayan Aileler Ne Yapsın Hususi Dadı mı Tutsunlar? (1969, 3 Nisan). Yeni Asır, 6.
} 
levi olmuştur. Ancak Hansen'in sinemaya giden kadınlara atfettiği özgürlük her toplumda, her zaman ve aynı şekilde var olmayabilir. Ellili ve altmışlı yıllarda sinemaya gitmek, Türkiye'de de kadınlar için bir dışarı çıkma vesilesidir. Görüşmecilerden Oya Düzgün (54) bu durumu şöyle ifade etmiştir: "Genç kızlar için en büyük gezme sebebi. Güzel giyinip dışarı çıkmak için." Bununla birlikte, kadınların rahatlıkla sinemaya gidebildikleri veya sinemada istedikleri gibi özgür bir seyir deneyimi yaşayabildikleri söylenemez.

Gazete haberlerinden, söz konusu dönemlerde, kadınlar için sinema mekânlarının her zaman erkek tacizine uğrama olasılığı taşıyan mekânlar olduğu anlaşılmaktadır. ${ }^{46}$ Öyle ki kadınlar yanlarında abileri, babaları veya eşleri olduğunda bile çeşitli sarkıntılıklara ve tacizlere maruz kalabilmektedir. ${ }^{47}$ Sözlü tarih kapsamında yer alan kadın görüşmecilerin sinemaya gitme anlatılarında, hep kendilerine eşlik eden bir baba, abi veya erkek kardeş; ya da anneyle birlikte bir teyze ve/veya bir / birkaç komşu teyze olduğu fark edilmiştir. Ayrıca erkek görüşmecilerin ailelerinden çok daha fazla arkadaşlarıyla, kadın görüşmecilerin ise arkadaşlardan çok aileleriyle sinemaya gittikleri de gözlemlenmiştir. Kadınların hem sokakta hem sinemada taciz ve rahatsız edilme tehdidi altında hissettikleri veya hissettirildikleri düşünülürse, sinemaya toplu gitmenin kadınlar için sadece hazdan değil, zorunluluktan da kaynaklandığı görülebilir. Örnek vermek gerekirse, 15-16 yaşlarında her Pazar babasıyla sinemaya gittiğini söyleyen Nevzer Gülersoy (83), mahalledeki kızların pek dışarı çıkmayıp daha çok birbirlerinin evlerine ve ancak bir büyük veya aile götürürse sinemaya gittiklerini ifade eder. Gülersoy, babası dışında sadece bir kez, o da mahalledeki bir teyzeden kendilerine eşlik etmesini isteyerek ve babasından "mevlide gidiyoruz" diyerek izin aldıktan sonra bir kız arkadaşıyla birlikte sinemaya gittiğini belirtir. Ancak, bilet alırken arkalarından gelmiş olan babasına yakalandıklarını da gülerek anlatır. Kendisine "neden mevlit" diye sorduğumuzda, Gülersoy, "o saatte başka nereye gideceksin iki kız bir kadın" şeklinde cevap vermiştir ki, bu cümle de kadınların kamusal alanla ilişkisinin kısıtlanmış bir ilişki olduğunun altını çizer. Gülersoy, ayrıca,

\footnotetext{
${ }^{46}$ Poliste (1954, 20 Mart). Yeni Asır, 5; Sinemada Bir Sadist (1957, 28 Haziran). Yeni Asır, 3i Sinemada Sarkıntılık (1958, 22 Şubat). Yeni Asır, 2; Sinemada Bir Genç Yanındaki Hanıma Saldırdı (1959, 16 Ekim). Yeni Asır, 3; Sinemaya Yalnız Giden Bir Kadına Sarkıntılık Edildi (1965, 15 Haziran). Yeni Asır, 3.

${ }^{47}$ Sarkıntılık Ettiği Kadının Kocasını da Bıçaklamış (1960, 8 Mart). Yeni Asır, 2; Babasının Yanında Kıza Sarkıntılıktan Tevkif Edildi (1966, 19 Ağustos). Yeni Asır, 3.
} 
sinemaya gittiklerinde babasının onu rahatsız etmesinler diye hep sıra başına oturttuğunu da eklemiş ve kadınlar açısından rahatsız edilme endişesinin hep olduğunu, durakta beklerken kızların eteklerini kaldıran erkeklere, bu tür hareketleri engellemek için yanında iğne taşıyan kızlara ve sinemada arkadan "dürten" erkeklere değinerek açıklamıştır.

Kadınların sinemada fiziksel tacize uğramasına engel olunsa bile, erkek bakışlarının nesnesi olmaktan kurtarılamadığı ise, Gülersoy'un, 16-17 yaşlarında bilet sırasında beklerken annesi ve babası arasında yaşanan bir diyaloğu anlattığı şu anekdotta görülebilir: "Annem kızıyormuş herkes bakıyor bana diye. Gitmeyelim o sinemaya diyormuş babama. Babam, neden gurur duy çocuğunla diyormuş. Çok da meraklıydım saç-başıma, bakıyorlardı. Meğer babamın da zevkiymiş o." Yıldız Sineması ile ilgili anılar toplamak üzere açtığımız Basmane Yıldız Sineması Hatıraları Facebook sayfasına gönderdiği bir yorumda Yıldız İlhan ise, babasının ve başka babaların, gerek kızlarını ve eşlerini erkek bakışlarından korumak, gerekse onların bakışlarını kontrol altında tutmak üzere, çeşitli yöntemler izlediklerini şu şekilde dile getirmektedir: "Rahmetli babamın tutuculuğu sayesinde biz üç kardeş ve annem yıllarca locada izledik filmleri. O dönemden böyle çok arkadaşım vardı hatta bir arkadaşımın babası aralarda etrafa bakamasınlar diye yanlarında kitap taşımayı şart koşardı sinemaya giderken." ${ }^{48}$

Görüşmelerde, kadınların nişanlılarıyla bile sokakta veya sinemada yalnız bırakılmadığı da dile getirilmiştir. Bir kadın görüşmeci, bu durumu, "nişanlınla sinemaya yalnız gidemezsin. Kardeşin vesaire cemi cümle. Ne o, nişanlınla sinemaya gittin" (Gülseren Çiftçi, 82), sözleriyle dile getirirken, bir başka kadın izleyici, çocukken nişanlı büyüklere nasıl refakatçilik yaptıklarını şu sözlerle açıklamıştır: "Bizden büyük ablalar nişanlı oluyorlardı. Onları yalnız bırakmıyordu büyükler. Bizi de yanlarına koyuyorlardı. Nişanlılar öne biz arkalarına oturuyorduk. Enişte bize akide şekeri, boyalı leblebi alırdı bayılırdık" (Sıdıka Kaçuna, 75). Erkeklerin bu konudaki deneyimlerini temsilen, bir erkek görüşmecinin yorumu ise şöyledir: "Nişanlıların en güzel gidebileceği yer ya gül bahçeleri ya da akşamları sinemalar vardı. O zamanlar nişanlınla yalnız gidemezdin. Yanına muhakkak ya kız kardeşi, ya annesi mutlaka takılırdı. Ben de dört bilet alır onlara sürpriz yapardım. Giyinirlerdi kuşanırlardı" (Mehmet Bazan, 65). Görüşmecilerden İhsan Helvacı (70) ise

${ }^{48}$ https://www.facebook.com/yildizsinemasiprojesi/ 9 Ağustos 2016 tarihli gönderiye 19 Ekim 2016 tarihinde yapilan yorum. 
toplumda bir türlü yalnız kalınamayan nişanlının kardeşine bu yüzden "jandarma" dendiğini ifade etmiştir.

Kadın görüşmeciler arasında sinemaya "kız kıza" gitmiş olanlar da vardır. Sıdıka Kaçuna (75), böyle bir durumda yaşadıkları rahatsızlıkları aşağıdaki şekilde açıklar.

Kimisinin abisi olurdu yanımızda o zaman daha rahat ederdik. Kız kıza gittiğimizde bak arka sıraya oturun, arkanızda kimse olmasın, duvar olsun diyorlardı. Bizim aklımız ermiyordu tabi. Yer bulursak öne de oturuyorduk. Bir baktık, arkamızda oğlanlar oturuyordu. Kimisi saçını çekiyordu. Kimisi ayağını poposuna dokunduruyordu. Rahatsız olmaya başladık. Büyüklerimize de söyleyemedik. O şeyleri de yaşadık. Saçımızı çekiyorlardı, kokluyor gibi yapıyorlardı, kafamızı kokluyorlardı arkamızdan. Rahatsız oluyorduk ama korkuyorduk da sesimizi çıkaramiyorduk.

Görüşmecilerden Bedriye Eriş (91) de İzmir Kız Lisesi'nde yatılıyken arkadaşlarla sinemaya gittiklerinde ortaya çıkan benzer bir durumu şu sözlerle ifade eder: "Bazen erkek talebelerden rahatsız olurduk, ama herhalde o da o devrin bir şeyiydi." Sinemaya küçükken teyzesiyle, teyzesinin komşuları ve onların kızlarıyla gittiğini söyleyen Alev Ersoy (78) ise, peşi sıra, "Öyle her sinemaya haldır huldur gitmezdik" açıklamasını yapar ve "erkeklerin gittiği iki film oynatan sinemalar" yerine Elhamra ve Tayyare sinemalarını tercih ettiklerini belirtir. Bununla birlikte, Tayyare'de bile teyzelerin başa, ortaya ve sona oturup kızları ortalarına aldıklarını da ekler.

Yıldız Sineması sahibi Yüksel Kazmirci (87), sadece kadınların değil çocukların da rahatsız edilmesini ve olası tacizleri önlemek ve her türlü olayda müdahale etmek için iki kişinin özel olarak görevlendirildiğini belirtmiştir ki bu açıklama birinci sınıf sinemalarda bile bu tür rahatsızlıkların olabildiğini gösterir.

Görüldüğü üzere, kadınların sinemaya aileyle ya da başka kadınlarla gitme durumu daha kaynaştırıcı ve şenlikli olmasından öte, eril baskılardan ve/veya tacizlerden de kaynaklanır. Söz konusu dönemin nostaljiyle hatırlanan kadın matinelerine de bu gözle yeniden bakmakta fayda olabilir. Bu matinelerin samimi ve şenlikli tarafı elbette yadsinamaz. Ancak, söylemdeki bu şenlik vurgusu, matinelerin, kadınlar üzerindeki sosyal kısıtlamaların aşımı için bir yol olduğu gerçeğinin üstünü örtmemelidir de. 


\section{"Sınırı Aşma" (transgression) Alanı Olarak Sinema Atmosferi}

Sinemanın kalabalık ve karanlık ortamı, onu potansiyel bir "sınırı aşma" (Akbulut, 2014, s. 11) veya "yasak bozma" alanı haline de getirir. Örneğin, görüşmecilerden İhsan Helvacı (70), Basmane bölgesindeki sinemalarda, perde önündeki ucuz sıralara esrar içenlerin geldiğini belirtir ve ekler: "Adam geliyor karanlıkta sigarayı sarıyor, oturuyor, hem film seyrediyor hem kafayı buluyor." Sinemaya bir sınır aşım alanı olarak işaret eden en yaygın anlatılar ise heteroseksüel çiftler arasındaki flört pratiklerine ilişkindir. Muhafazakâr bir toplum ortamında sinemanın sağladığı birliktelik ortamı, sinema salonlarını, kadın-erkek karşılaşmaları, bakışmaları ve buluşmaları için elverişli ortamlar kılar (Öztürk, 2013 , s. 23). Yapılan görüşmelerde, sinemanın bu yönü, daha çok, özelde yaşanan değil şahit olunan bir durum olarak dile getirilmiştir. Bununla birlikte, bir kadın görüşmeci, yazlık sinemada komşunun kızlarıyla birlikte tanıdık gençlerle bakışmanın hoşuna gittiğini ancak anne-baba ile gidildiği için tanışmanın söz konusu olmadığını dile getirmiştir (Nevzer Gülersoy, 83). Bir erkek görüşmeci de yazlık sinemalara "acaba sevdiğimiz, hoşlandığımız kızı görebilir miyiz?" diyerek gittiklerini ifade etmiştir (Mehmet Bazan, 65).

Kapalı sinemaların, kalabalık kamusal alanlar olmalarına rağmen, gündüz vakti bile karanlık ortamlarıyla, bir mahremiyet hissi sundukları ve cinsel yakınlaşmalara dahi olanak tanıdıkları görülür. Gazete haberlerinde sinemalarda "uygunsuz hareketlerde" yakalanan çiftlere rastlanır. ${ }^{49}$ Örneğin, "bir inşaat işçisi metresiyle birlikte" bir sinemada beş saat vakit geçirmiş ve "uygunsuz hareketler" sergilemesi üzerine sinema personeli tarafından dışarı çıkarılmak istenince olay çıkmıştır. ${ }^{\circ 0}$ Bir başka habere göre, "genç bir erkek ve bir kadın," "gayri ahlaki bir vaziyette" görülerek sinema personeli tarafından polise teslim edilmiş, yapılan soruşturmada kadın ve erkeğin evli oldukları anlaşılınca ortaya ilginç bir haber olayı çıkmıştır. Haber, şöyle devam etmektedir: "Neticede bunların bir evin bir odasında kiracı oldukları, on beş günden beri de erkeğin annesi ile hemşiresinin kendilerinde misafir bulundukları, skandalın da bu sıkışık durumdan ileri geldiği meydana çıkmıştır." Haberde, genç karı-koca hakkında "alenen hayâsızca harekette bulunmak" gerekçesiyle dava açıldığı da bildirilmektedir. ${ }^{51}$

\footnotetext{
${ }^{49}$ Sinemada Uygunsuz Yakalandılar (1966, 6 Eylül). Yeni Asır, 3.

${ }^{50}$ Sinemada Cinayet İşlendi (1965, 23 Ocak). Yeni Asır, baş sayfa ve s. 2.

${ }^{51}$ Sinemada Fena Vaziyette Yakalanan Karı-koca (1957, 1 Kasım). Yeni Asır, 5.
} 
Sinemada mahremiyet duygusunu daha az riskle yaşamak isteyen çiftlerin, bunun için balkon kısmının arka taraflarını veya daha fazla ücret ödeyerek locaları seçtiği görülür. Görüşmecilerden bazılarının bu durumla ilgili izlenimleri aşağıdaki gibidir:

Localara âşıklar giderdi. Orada artık malum... Gündüz seanslarına gene böyle sevgililer gelirdi. Onlar da balkonun en arka köşe taraflarına otururlardı. Artık yarı film seyrediyorlardı, yarı... konuşuyorlardı, neyse (İhsan Helvac1, 70).

Localara âşıklar giderdi. Ben sinemaya hep babamla gittiğim için, locaya hiç gitmedim. Sevgilim olsa belki giderdim (Nevzer Gülersoy, 83).

1959 yılına ait bir gazete haberi, daha o yıllarda, sinemalardaki locaların özel ilişkilerin yaşanabileceği mekânlar olarak algılanışına ilişkin bir fikir vermektedir. Habere göre, sinemaya içkili olarak gelen Karadenizli zengin bir şahıs bir loca tutmuş ve sinema personelinden kendisine refakat edecek bir kadın arkadaş istemiştir. İsteğinin yerine getirilmemesi üzerine olay çıkarmaya çalışan kişi sinema salonundan çıkarılmış ve hakkında kanuni işlem yapılmıştır. ${ }^{52}$

Şükrü Yılmaz'ın (70) aşağıdaki yorumu, sinemada mahremiyet duygusu yaşamanın mümkün olmakla birlikte, gene de çaba gerektirdiğini ve tam bir mahremiyetin loca dışında mümkün olmadığını göstermektedir:

Localar onlar [sevgililer] için oluyordu zaten. Kız arkadaşını alır giderdin mesela. Sevişirdin mevişirdin, hep locada olurdu onlar yani. Ama balkonda salonda olmazdı. Salonda el ele tutuşma gibi şeyler de olmazd. Balkona giderdin. En arkalarda otururlardı. Takip ederdik yani biz de. Bak ya derdik. Almış kız arkadaşını gidiyor.

Yılmaz'ın açıklaması, kendilerini hem toplumun hem sinemadakilerin meraklı ve kontrol edici bakışlardan uzak tutmak isteyen çiftlerin, her ne kadar kendilerini sinemalarda görünmez kılmaya çalışsalar da bu bakışların nesnesi olmaktan kaçamadıklarını gösterir. Açıklama, aynı zamanda, sinemada bakışın sadece perdeye doğru, tek yönlü bir bakış olmadığının, bir başka deyişle, seyircilerin sadece perdedeki filmi değil birbirlerini de izlediklerinin, hatta gözetlediklerinin, altını çizer.

\section{Sinemada Başkalarını Görmek, Başkalarına Görünmek}

Sinemaya gitmenin popüler bir sosyal aktivite olması, sinema salonla-

\footnotetext{
${ }^{52}$ Sinemada "illle de avrat isterim" Diye Tutturdu! (1959, 26 Mayıs). Yeni Asır, 2.
} 
rını karşılaşma mekânları yapar. Sinemanın mümkün kıldığı bu karşılaşmalar ayrıca bir zevk kaynağı olabilir. Sinemaya her şeyden önce kaliteli film izlemek için gittiğini belirten Mustafa Çalışık (65), gene de sinemaya gitmenin film izlemenin ötesinde duyguları ve yan anlamları harekete geçirdiğini ima eder şekilde şu açıklamada bulunur: "Ama gidince başka muhitten insanları görme, o da hoş oluyordu. Aileler oluyordu. 300-500 metre arabalar arka arkaya park ediyordu." Çalışık'ın bahsettiği sinema, Basmane'deki Yıldız Sineması'dır. O dönemde kentin merkezi olan Basmane'nin tren garı ve otobüs garajı sayesinde kolay ulaşılabilir olmasından da kaynaklı olarak, Yıldız Sineması, özellikle hafta sonları ve akşamları, farklı muhitlerden seçkin aileler de dâhil olmak üzere geniş kalabalıkları kendine çeker. Çalışık Yıldız'a Kordon'dan, Karataş'tan gelenleri hatırlarken, bir başka görüşmeci, İhsan Helvacı (70), hafta sonu akşamları Güzelyalı'dan, Karşıyaka'dan, Bornova'dan gelenler olduğunu belirtmekte ve arabalarla gelen seçkin ailelere değinmektedir. Sinemada çocukluğu ve gençliği geçmiş Osman Işıkalp (51) da Basmane'de orta sınıf ailelerin oturduğunu belirterek, Ylldı'a "İzmir'in zengin semtlerinden" gece kıyafeti ve takım elbiselerle, "taksilerle gelen bir kitle" olduğunu vurgulamıştır. Yıldız Sineması'nın, bu yönüyle, Elhamra ve Tayyare gibi seçkin sinemalardan farklı olarak, Basmane'nin orta halli insanlarını İzmir'in seçkin çevreleriyle buluşturduğu ve filmlerin yanı sıra bu çevreleri de onlar için bir seyir nesnesi haline getirdiği düşünülebilir.

Sinemada sadece faklı muhitlerden insanlarla değil; mahalleli veya arkadaşlarla da karşılaşılır, sinema filmin ötesinde bir iletişim alanı haline gelir. Bunun yanı sıra, seyircilerin, sinemaya gelen yabancı veya tanıdık başkalarını görmekten olduğu kadar, kendilerini başkalarına görünür kılmaktan da zevk duydukları anlaşılır. Ali Ulvi Tunalı (65), sinemada görünmenin, kendini başkalarına görünür kılmanın anlam ve önemini aşağıdaki şekilde açıklar:

Sinemaya gidiyor olabilmek insanlarla iletişim de sağliyordu. Bir tanıdığı görmek mümkündü. Bak bizi de gördüler. Onlar da sinemaya geldiğimizi görsünler. Ben bir arkadaşımı gördüğümde onun da beni görmüş olması ayrı bir hazdı. Kolay bir şey de değildi sinemaya gitmek. Dolayısıyla orada göründüğümüz zaman böyle bir ayrıcalığı yaşıyor olmanın hazzı vardı. Onun için giyinip kuşanılıp gidilirdi. Ya biri bizi görürse diye bir endişe vardı orada. 


\section{Sinema Salonu ve Sosyoekonomik Siniflar}

1960-1980 arası dönemde Türkiye'de sinemaya gitme deneyimini sözlü tarih üzerinden inceleyen Hasan Akbulut, sinemaya gitme deneyiminin, heterojen seyirci kitlesini "aynı amaç ekseninde bir araya gelmiş homojen bir gruba dönüştürdüğünü" söyler. Akbulut'a göre, sinema bu şekilde seyirci topluluklarına "sınıfsız, imtiyazsız, kaynaşmış" bir kitleye, bir "biz" e ait olma duygusu yaratır (2014, s. 6-7). Bununla birlikte, Akbulut, sinıfsal konumun sinema salonu ve film seçiminde etkili olduğunu ve daha çok giyilen kıyafetlerle dışa vurulduğunu da ekler (2014, s. 6). İzmir bağlamında gerçekleştirilen bu çalışma kapsamında yapılan görüşmelerde, sinemaya gitme ve film izleme deneyiminin birleştirici ve kaynaştırıcı etkisi sadece bir kişi tarafından açık şekilde dile getirilmiştir: "Bizim için her film bir anıydı. Hem eğlendirici oyalayıcı, hem insanları kaynaştırıcı. Kitlesel buluşmalar oluyordu. Her gün yüzlerce insanla buluşuyorsun. Herkes beyaz perdeye kilitlenmiş" (Sadullah Kement, 66). Bununla birlikte, görüşmelerin genelinde, seyircilerin sinemaya gitme deneyimlerinde, Akbulut'un işaret ettiği "sınıfsız, imtiyazsız, kaynaşmış" bir "biz" duygusuna rastlanmamıştır.

Öncelikle, Akbulut'un çalışmasının gösterdiği ve bizim de yukarıda tartıştığımız gibi, sinemaya gitmek, tek ve aynı amaç gibi görünse de içinde çoğul ve farklı niyetleri / motivasyonları barındırır. Daha da önemlisi, sinemalar arası sınıfsal farklar olabildiği gibi, ${ }^{53}$ tek bir sinemanın içinde bile sınıfsal bir yapılanma söz konusudur. Bir başka sözlü tarih çalışmasında da tespit edildiği üzere, söz konusu dönemde sinema salonları, oturma düzenleri açısından oldukça hiyerarşik bir yapıdadır (Öztürk, 2013, s. 24). Örneğin, her kesimden insanı bir araya getiren Yıldız Sineması'nın oturma, merdiven ve giriş-çıkış düzeninin nasıl yapılandırıldığına bakılacak olursa, bu mekânın farklı sınıfları bir araya getirse bile kaynaştırıcı olmadığı görülecektir.

Yüksel Kazmirci'den (87) alınan bilgiye göre, 1800 kişilik sinemada oturma yerleri salon, koltuk, balkon ve loca olmak üzere dört tür olup ayrı ayrı fiyatlara sahiptir. Bunlardan en ucuzu, perdeye en yakın olan, açılır-kapanır tahta koltuklu salon kısmıdır ve yaklaşık 200-250 kişi almaktadır. Salonun hemen arkasından takriben 1000 kişilik koltuk bölümü gelir. Bu bölüme koltuk denmesinin sebebi salondan farklı

\footnotetext{
${ }^{53}$ Sözlü tarih görüşmelerinde, özellikle iki sinemanın (Elhamra ve Tayyare) "seçkin," "asil," "kültürlü," "şık şapkalı" ve "güzel kıyafetli" gibi sıfatlarla nitelenen kimselerin geldiği, sınıfsal açıdan ayrıcalıklı sinemalar olarak anıldığı görülmüştür.
} 
olarak vinleks kaplı koltuklardan oluşmasıdır. Balkon kısmı ise koltuk kısmından biraz daha pahalı olup 500 kişiliktir. Balkonun da üstünde, ayrı bir merdivenle çıkılan, en yüksek bilet ücretine sahip, her biri 5 kişilik 12 adet loca bulunur.

Sözlü tarih görüşmesi yapılan kişiler, sinemalarda çoğunlukla balkon kısmına gittiklerini belirtmiştir. İçerdiği başka rahatlıkların yanı sıra, balkonun daha iyi görüş sunduğu da belirtilmiştir. Salon ve koltuk kısminda zemin eğimli değil düz olduğu için perdeyi tam görememeye yol açabilmektedir (Şeref Şakar, 74). Bununla birlikte, gençlikte paraları olmadığı için salon veya koltuk kısmında oturduklarını söyleyenler de olmuştur (Şükrü Yılmaz, 70). Görüşmecilerin çoğu locaya neredeyse hiç gitmemiştir. Alınan bilgilere göre, salon kısmı öğrenci, işsiz ve ekonomik olarak en alt sinıflar tarafından kullanılır. Koltuk kısmında ise ekonomik durumu daha iyi olan, çoğunlukla erkek seyirci görülür. Orta gelirliler, kadınlar ve aileler ise balkonu tercih eder. Localar ekonomik olarak üst veya orta-üst sinıf aileler tarafından kullanılır. Sinemanın ekonomik ve sosyal konum açısından bu ayrıştırıcı yapısı görüşmecilerin ifadelerine çeşitli şekillerde yansımıştır. Örneğin, gençliğinde arkadaşlarıyla Yıldız Sineması'na gittiklerinde, ara sıra balkona "kaçsalar da" paraları az olduğu için genelde salon kısmında oturduklarını belirten Şükrü Yılmaz (70), sinemaya her kesimden insanın geldiğini söylemesinin ardından şu cümlelerle devam eder: "Böyle kendini beğenenler vardı mesela. Kalantor olanlar. Localara giderlerdi. Ya da balkona... Orta kısım halk da salondan itibaren doldururlardı." Sinemanın eski makinist yardımcısı Ferruh Özdemir (67), balkondan farklı olarak numarasız olan salona gelenlerin, sabahtan akşama kadar oturma hakkına sahip olduklarını ve bu yüzden salonun "biraz da garibanların sığınma yeri" olduğunu belirtmiştir. Sinemanın hiyerarşik yapısının çok farkında olan görüşmeci Ali Ulvi Tunalı (65) ise yer tercihini açıklarken, bu tercihin nasıl bir sosyal anlam ve haz taşıdığını aşağıdaki şekilde tarif etmiştir:

Genelde balkonda otururdum. Balkonda izlemek statü, gurur vericiydi. Aşağıda balkonun altındasınız ama balkonda aşağıdakilerin üstündesiniz falan. İnsan psikolojisi böyle bir şey. Evet, balkonda seyretmeyi tercih ederdik. Bu filmin verdiği hazza bir şey katardı yani. Ama çok özel yerler değildi. 300 kişi falan alıyordu.

Daha üst sınıflara hizmet eden localar, fiziksel olarak en yukarıda konumlandırılışlarıyla, balkona kıyasla daha da ayrıcalık hissi taşıyan 
yerlerdir. Localar, aynı zamanda, sinemadaki bakma-görme ilişkileri açısından da en iktidara sahip konumdadırlar. Locadakiler alttakilere görünmezken onları görebilirler. Balkondakiler, balkon kısmının salonun yarısına kadar uzandığı için alttakileri ayağa kalkmadan göremezken (Süleyman Kalkan, 73), locadakiler, her açıdan en zengin seyir konumuna sahiptirler. Bir görüşmecinin "bir de orada [locada] en tepeden bakma gibi bir şey de var" (Şeref Şakar, 74) sözleriyle anlatmaya çalıştığı, locaların görme açısından sahip olduğu iktidar konumunu, sinemada çocukluğu geçen Osman Işıkalp (51) de şu sözlerle açıklamaktadır:

Ben balkonda film izlemeyi severdim. Birkaç defa da, boş olduğu dönemlerde, izin alıp locadan, üstten izlemeyi de severdim. İnsanları gözlemlemek anlamında. Filmle ilgilenmeyen, flört eden insanları da oradan görebilirdiniz [...] Balkon salonun yarısına kadar uzanırdı. Oradan salonu göremezsiniz ama locadan görünürdü.

Sinemanın fiziksel ve sosyal açıdan hiyerarşik yapısının seyirciler arasında herhangi bir gerilime veya çatışmaya yol açıp açmadığı sorulduğunda, görüşmeciler, böyle bir durumun olmadığını, zira hem salon ve koltuk kısmının hem de alt kat ve balkon kısmının girişlerinin farklı olup, farklı kısımlarda oturanların pek de yüz yüze gelmediklerini ifade etmişlerdir. Bu durumu bir görüşmeci şu şekilde açıklamıştır: "Salondakilerle balkondakiler karşı karşıya gelmezdi ki. Girişte zaten oturacak yer yoktu. Giriyordun içeriye. Biletini veriyordun. Oradan geçiyordun. Yukarı oturacaksan yukarıya, aşağı oturacaksan aşağıya" (Süleyman Kalkan, 73).

Girişlerin yanı sıra, aralarda kullanılan alt kat ve balkon fuayeleri ve büfeleri de farklıdır. Osman Işıkalp (51), balkon fuayesini kastederek, çocuk veya genç olarak o zamanlarda bu mekânı nasıl algıladığını şu sözlerle ifade etmiştir: "Bu mahaller, fuaye kısımları, iç dizaynı bana tiyatro hissi verirdi. Buranın seyirci profili kahve, çay bahçesi kitlesi değildi." Genelde balkon kısmını tercih eden Mustafa Çalışı (65) da bu kısmın büfesiyle hizmetinin daha iyi olduğunu belirtmiştir.

Görüldüğü üzere, aslında sinemada farklı kesimler arasında fiziksel bir birliktelik veya kaynaşma yoktur. Böyle bir kaynaşmanın imgelemde olup olmadığını tespit etmek veya kolayca anlamak mümkün değildir.

Gerek Yüksel Kazmirci'den (87) gerekse sözlü tarih kapsamında görüşülen kişilerden edinilen bir başka bilgi de sinemadaki seyirci kompozisyonunun, bir başka deyişle sosyal dokunun, gece-gündüz ve hafta 
içi-hafta sonu eksenlerinde değişen yapısına ilişkindir. Sinemanın içi zamanda sabit değil değişken bir mekândır. Görüşmecilerden ikisi, bu mekânın gündüzden akşama, hafta içinden hafta sonuna demografik olarak nasıl doku değiştirdiğini aşağıdaki şekillerde ifade etmişlerdir:

Sinemaya gündüz gelen insanlar başka gece başka. Aileler akşam gelirdi. O saatte aşağı gelen insanlar da daha iyiydi. Orta kültürlü insanlar vardı burada ama kötüler de vardı. Esrar içen de vardı. Hırsız da vardı. Sinema umuma açık bir yer. Bu anlattığım şeyler gündüz olan şeyler. Gece farklı (İhsan Helvacı, 70).

Gece seanslarına giyimiyle kuşamıyla özel bir temsile, tiyatroya gider gibi giderdik. Hatta matine ve suare diye seanslar ayrilırd.. Yani seansların karakteri de isimlendirildi. İlk seanslarda izleyici kalitesi düşüktür. İşi olmayan giderdi. Akşam, ekâbir takımı mı diyeyim artık, işte ailelerin, kalburüstü kişilerin, işinden çıkıp, eve gidip, yemeğini yiyip, giyinip sinemaya gidecekler için. Gece geç seanslara kültür seviyesi daha yüksek giderdi (Ali Ulvi Tunalı, 65).

Yüksel Kazmirci (87), sinemanın program ve biletleme biçiminin de zamana göre değiştiğini ifade etmiştir:

Müşteri çekmek için buradaki [Basmane] bütün sinemalar iki birinci vizyon film oynardl. Prensip olarak bir tanesi avantür, bir tanesi de daha biraz aileyle ilgili. Peş peşe gösteriliyor. Bir giren iki film seyreder. Devamlı girer müşteri içeri, istediği kadar kalırdı. Ancak suarelerde balkon numaralı olduğu için, suareye göre bir evvelki seansta müşteri alınmazdı. Suarelerde sinema boşalır, numaralı olarak balkona alınır [...] Loca gündüz daha rahat bulunur ama suareler için önceden rezervasyon yapmak gerekirdi. Numaralı biletler için de geçerliydi. Gündüz telefonla ayrılır. Gece gişe iki taraflıydı. Bir taraftan normal müşteri, diğer taraftan telefonla bilet ayırtan müşteri biletini alırdı. Yani hem Basmane'nin en avantür müşterisi gelirdi, ama bir sürü konsolosların, belediye reisinin çok geldiği de bir yerdi.

Sözlü tarih görüşmelerinden, Yıldız Sineması ve civarının hafta sonları, özellikle cumartesi akşamları adeta başka bir yere dönüştüğü hissi edinilir. Sinema önünde arabalar sıralanır, şık giysili hanımlar ve beyefendiler sinemaya girer. Sinemanın hafta sonu müdavimlerinden birisi de, yukarıdaki alıntıda Yüksel Kazmirci'nin de sözünü ettiği gibi, 1964-1973 yılları arasında İzmir Belediye Başkanı olan Osman Kibar'dır. Ylldız Sineması'nın eski baş makinisti Rüstem Çetin (82), Kibar'ın sinemaya geldiği günleri şu sözlerle anlatır: "Osman Kibar (asfalt Osman) her cuma 6 numaralı locaya gelirdi. O loca tam ortaya gelirdi. Vali bey de cuma veya cumartesi gelirdi. $O$ da 6 numaraya gelirdi. Polisler gelir- 
di buraya. $O$ trafik baştanbaşa araba olurdu. Aylık kupon satıyorduk. $O$ zaman resmi bir daire gibiydi burası" (Rüstem Çetin, 82).

\section{Sinema, Kent ve Modernlik}

Sinema kentsel bir mekândır. 2017 itibariyle, halen Buca'da bir açık hava sineması işleten Tarık Kara (75), ellili yıllarda, Buca'da sinema görmeyenlerin çok olduğunu, bu yüzden İzmir'e gidenlere "sinema gördün mü?" diye sorduklarını belirtmiştir.

1963 yllından bir gazete yazısında, o dönemde pek çok sinemanın da konuşlandığı Tepecik, Basmane ve Eşrefpaşa semtleri, İzmir'in en çok suç işlenen üç büyük semti olarak ele alınır. Yıldız Sineması'nın da bulunduğu Basmane, sadece "hareketli bir eğlence mevkii" sabıkalıların kol gezdiği, kumar ve kadın satışı da dâhil olmak üzere pek çok suçun işlendiği bir bölge olarak tarif edilir. ${ }^{54} \mathrm{Bu}$ tabloyu destekler şekilde, gazete haberleri, sinemaların da hırsızlıktan ${ }^{55}$ bazen ölümle de sonuçlanan kavga ve hesaplaşmalara kadar pek çok suç olayına sahne olduğunu gösterir..$^{56} \mathrm{Bu}$ bağlamda sinemaların sadece bir seyir mekânı değil aynı zamanda bir suç mahalli olduğu söylenebilir. Bununla birlikte, bu çalışma kapsamında yapılan görüşmelerden, daha önce başka benzer çalışmalarda da tespit edildiği üzere (Akbulut, 2014), sinemaların aynı zamanda kent ve modern yaşam kültürünün öğrenildiği veya deneyimlendiği mekânlar olduğu da açıktır. "Sinema diye bir şey vardı ama bunun kültürü sonradan oluştu. İzleyici olmak kültürü başka" diyen Ali Ulvi Tunalı (65), bu konuda aşağıdaki açıklamayı yapar:

Sinemanın disiplin edici, öğretici bir yanı da vardı. Nasıl oturulur, izlenir, sıraya girme, toplumsal olarak bir yere girme çıkma, susmasını öğrenme... Kültürlendirici. Bir camiye girerken kuralları usulleri var. Sinemaya girerken de kuralları usulleri var. Bu mekânların yok oluşu bir kültürün yok oluşu demektir.

Türk toplumunda "kuyruk terbiyesinin" 1960 askeri ihtilaliyle

\footnotetext{
${ }^{54}$ Tepecik-Basmane-Eşrefpaşa: İzmir'in En Çok Suç İşlenen 3 Büyük Semtinde Halk, Tedbir Alınmasını İstiyor (1963, 8 Ağustos). Yeni Asır, 8.

${ }^{55}$ Sinemada Hirsızlık (1957, 3 Aralık). Yeni Asır, 4; Sinemada Yankesicilik (1958, 16 Nisan). Yeni Asır, 2; Sinemada Çarpılan Kadın (1962, 3 Temmuz). Yeni Asır, 2; Sinemada Bir Kadının Cüzdanını Çalan İki Genç Kız Yakalandı (1965, 9 Ağustos). Yeni Asır 3.

${ }^{56}$ Poliste (1953, 6 Eylül). Yeni Asır, 4; Sinemada Yaralama (1957, 19 Eylül). Yeni Asır, 2; Sinemada 'Rezalet' Çıkarmıştı (1963, 21 Ağustos). Yeni Asır, 2; Sinemada Film Seyrederken İskemlesine Ayak Koyan Genci Bıçakla Vurdu (1966, 14 Ocak). Yeni Asır, 3; Agora'da Bir Genç Sinemada Film Seyrederken Öldürüldü (1970, 22 Mayıs). Yeni Asır, 1.
} 
başladığını belirten Yüksel Kazmirci (87), önceleri herkesin birden gişeye saldırdığını, ancak zamanla kuyruğa girerek bilet almayı öğrendiğini söyler. Babasının sinemada müdür olması nedeniyle neredeyse Yıldız Sineması'nda büyüyen Osman Işıkalp de (51) sinemanın "kuralları olan bir şey" olduğunu belirterek şu örneği verir: "[Hafta sonlarında] kapalı gişe oynadığı için arada sinemaya girme olayı yoktu. Gösterim başlamiş, alınmadığına şahit olduğum kişiler oldu. Bir nevi tiyatro kuralı." Işıkalp ayrıca, sinemanın mekânsal özellikleriyle ve içindeki farklı insan pratikleriyle kendisi için bir okul olduğunu dile getirir:

Ben orayı okul gibi değerlendirdim. Hem insanların hal ve hareketlerini, sosyal çevreyi gözlemleme, hem de idari ve teknik olaylar vardı [...] İçyapısı çok lükstü. Duvarlardaki apliklerden merdiven tırabzanının tahta kaplamasına kadar çok değişik gelirdi [...] Film aralarında veya film başlamadan önce kamu spotu gibi bilgilendirmeler yapıldığını hatırlıyorum. Temizlik kuralları, aşı, görgü kurallarını anlatan bilgilendirmeler. Eğitime yönelik de bir şey vardı. Kim organize ediyordu bilmiyorum. Belki bir mecburiyetti.

Osman Işıkalp sinemada gösterilen eğitici-öğretici filmlerin sinemanın inisiyatifiyle gösterilip gösterilmediğinden emin olamasa da, Yüksel Kazmirci'nin anlattıkları, sinemada bir adap oluşturmak yolunda epey çaba sarf ettiklerini göstermektedir. Kazmirci, özellikle gündüz seanslarına ve avantür filmlere, erkek kalabalıkların temsil ettiği "toplum terbiyesi" ve "sosyal alışkanlığı" olamayan halk kesiminin geldiğini ifade eder ve sırf içerinin düzeninin ve emniyetinin sağlanması için iki kişiyi özel olarak görevlendirdiklerini belirtir. Bu kişiler kaçak sigara içme, ayakkabılarını çıkararak film izleme, gürültü yapma, kavga etme ve başkalarını rahatsız etme gibi durumlarda seyircileri uyarmakta veya müdahale etmektedirler. Kazmirci, bu konuda verilen uğraşlarla "sinemaların halkın terbiye kazanmasında büyük rolü olduğunu" ifade eder.

Yıldız Sineması'nda kaçak sigara içerken yakalandığını belirten Şükrü Yılmaz (70), böyle durumlarda sinema görevlilerinin nazik üslubunun da öğretici bir yanı olduğuna dikkat çeker: "Görünce sigarayı söndür derlerdi. Çıkarıp kolundan atmazlardı. Lütfen sigarayı söndürün derlerdi." Yılmaz, sinemanın bir adabı olduğunu anlatırken de sinema çalışanlarını dışarıda bırakmaz ve ekler: "Fenerciler [teşrifatçılar / yer göstericiler] bile feneri kapatarak yer gösterirdi." Bununla birlikte, Yüksel Kazmirci (87), sinemadan "terbiyesizlik yaptığı için dayak yiyip atılanların da olduğunu" ifade etmiştir. "Başka türlü başa çıkamazdınız" diye de açıklama yapan Kazmirci, belli durumlarda sinema 
görevlilerinin müşteriye karşı fiziksel şiddet uygulaması konusunda, Basmane Polis Karakolu ile de gayri resmi bir anlaşmalarının olduğunu aşağıdaki anekdotla anlatır:

Biri dövülmüş atılmış. Dövüldüğüne göre ya bir hanımın yanına oturmuş bacağını sıkıştırmaya kalkıyordur ya da oğlan çocuğunu bilmem ne yapıyordur. Böyle durumlarda iki tokat atılırdı bir daha gelmesin diye. Biri beni karakola şikâyet etmiş. Karakolda neden bize haber vermediniz, dövdünüz dedi komiser. Bakın dedim ben yüksek tahsilliyim hiç öyle sadistliğim falan da yok. Biri dövüldüyse bilin ki şu iki sebepledir. Öyle sigara içmiş falan değil. Ya bir hanımın yanına oturmuş bir şey yapıyordur ya da bir oğlan çocuğunu helaya götürmeye çalışıyordur falan. İstiyorsanız baş komiserim, her olayda ben size telefon açayım, polis gelsin o halletsin, ben elimi sürmeyeyim daha rahat ederim. Ama inanın karakolun kadrosu yetmez dedim. Çünkü gelen binlerce kişinin toplum terbiyesi, o sosyal alışkanlığı yok. Baş komiser, "tamam Yüksel Bey bundan sonra gelene iki tokat da ben atarım" dedi. Sadece biz değil buradaki bütün sinemalar böyleydi.

Yıldız Sineması'nın sinemada adap, disiplin ve düzen konusundaki yaklaşımının İzmir'in tüm sinemalarındaki durumu temsil ettiği söylenemez. Yapılan görüşmelerden, özellikle sadece yerli veya avantür, iki-üç film gösteren veya ikinci, üçüncü sinıf sinemalarda, daha serbest, gürültülü ve kaotik bir ortam olduğu anlaşılmaktadır. Görüşmecilerden biri bu duruma şu sözlerle değinir: "Yeni Sinema'da, Büyük'te, Konak'ta gürültü olurdu. Çoluk çocuk da gelirdi. Yeni Sinema'da kovboy filmleri falan... Ama Elhamra, Tayyare, İkbal'de gürültü olmazdı" (Alev Ersoy, 78). Bir başka görüşmeci, Şükrü Yılmaz da (70) Yıldız'da gürültü hatırlamaz ve yerli film gösterilen "Büyük Sinema'da olurdu gürültü" der. Bununla birlikte, gerek Yüksel Kazmirci gerekse sözlü tarih görüşmesi yapılan bazı seyirciler, yetmişlerin ortasından itibaren, gösterilen filmlerin ve seyirci kalitesinin düşüşüyle, Yıldız'da da kuralların gevşediğini, pek çok şeyin serbest bırakıldığını belirtirler. Örneğin içerde müdahalesiz şekilde sigara içmeler, kabuklu çerez tüketimi ve gürültü patırtı seyir deneyimine eşlik etmeye başlar. Görüşmecilerden biri bu dönüşümden kısaca şöyle bahseder: "Sinemada çekirdek yenmezdi, tertemizdi. Sonradan bozuldu. Sinemalar düşmeye başlayınca herkes serbest bıraktı" (Şükrü Yılmaz, 70). Ylldız Sineması'nın başlarda nezih bir aile sineması olduğunu belirten bir başka görüşmeci ise sinemanın değişimini Basmane'nin zaman içinde değişimine de bağlamıştır: "Göçle Basmane dönüşünce Ylldız da eski özelliğini kaybetti. Ondan sonra zaten bırakıp halı saha yaptılar" (Ahmet Erbilgici, 63). 


\section{Seyir ve Alımlama}

Yukarıdaki bölümlerde tartışıldığı üzere, sinemalar kalabalık ve karanlık ortamlarıyla, film seyretmenin yanı sıra kalabalıkta kendini gizlemekten görünür kılmaya, duygusal ve cinsel yakınlaşmalardan sosyalleşmeye, yankesicilikten esrar tüketimine kadar bir dizi başka faaliyeti de mümkün kılan kamu alanıdır. Bir başka deyişle, sinema salonundaki "performans" sadece perdede oynayan filmle sınırlı değildir (Allen, 1990, s. 352). Televizyon öncesi dönemlerde sinemaya gitmenin her şeyden önce bir alışkanlık olduğu, hatta seyircilerin sinemada oynayan filme çoğu zaman dikkat bile etmediği söylenir (Ellis, 1982, s. 26; Corrigan, 1983, s. 31; Allen ve Gomery, 1985, s. 157; Allen, 1990, s. 352). Bununla birlikte, bu çalışma kapsamındaki görüşmelerde, film izleme deneyiminin, filmin türüne ve içeriğine de bağlı olarak, sinemaya gitmeyi motive eden başat unsur olduğu gözlemlenmiştir. Bu bölümde bu seyir deneyiminin bileşenlerini filmlere atfedilen anlamlarla birlikte tartışıyoruz.

Ellili ylllardan yetmişlerin sonuna dek yerel basındaki film reklamlarında ve karikatürlerde sinemanın popüler bir eğlence ve alışkanlık olarak tasvir edildiği görülür. Bu temsillerde, özellikle kadın seyirci sinemaya gitmekten, hatta kaçmaktan kendini alıkoyamayan, sinemada yaşam ve geçim derdi gibi gündelik sıkıntılarını unutan, evlilik hayatında tam olarak tatmin edemediği sevgi ve aşk duygularını duygusal filmlerle karşılayan bir figür olarak karşımıza çıkar. Bu bağlamda, sinemanın ve sinemada seyirci olmanın en başta kaçış (escape) duygusuyla ilişkilendirildiği görülür ki, bu kaçış kavramı küresel düzeyde popüler sinemaya daima atfedilmiş bir özelliktir. Yapılan sözlü tarih görüşmelerinde katılımcılara onları filmlere çeken etmenler sorulduğunda veya bu konu anlattıkları diğer şeylerden çıkarılmaya çalışıldığında ise, yorumların, kaçış duygusundan ziyade merak, ihtişam, heyecan, gerçeklik hissi ve inandırıcılık gibi temalar etrafında dolaştığı görülmüştür. Bununla birlikte, bu durumun sinemalarda gösterilen ve görüşmecilerin seyretmeyi tercih ettiği filmlerin niteliğiyle de yakından bir ilgisi olabilir. Bu çalışma kapsamında görüşülen kişilerin (kadın veya erkek) çoğunun, Zeki Müren filmleri gibi belli birkaç istisna dışında, yerli filmlere gitmediği, yabancı dublaj filmleri tercih ettiği görülmüştür ki bunlar çoğunlukla kırklı yılların ortasından itibaren Türkiye'de de hâkim olan Amerikan filmleridir. ${ }^{57}$ Daniel Lerner, Türk modernleşmesi üzeri-

${ }^{57}$ Amerikan filmlerinin Türkiye film pazarındaki hâkimiyetinin gelişimi ve popüler imge- 
ne olan The Passing of Traditional Society (1964) kitabında, ellili yllların ortasında İstanbul'da gerçekleştirdiği bir anketin sonuçlarına dayanarak, Türkiye'de "modernlerin" yabancı / Amerikan filmlerini "daha heyecanlı" bulup tercih ederken, "geleneksellerin" yabancı filmlerle çok da ilgilenmediğine değinir (aktaran Gürata, 2007, s. 347). Bu çalışmaya katılan görüşmecilerin çoğu Amerikan filmlerini tercih etse de bu tercihlerini başlı başına sorunlu olan geleneksellik-modernlik ikiliğiyle açıklamak mümkün değildir.

Lamek Film Sinema Postası altmışlı yılların ortasında İzmir'de yerli film gösteren sadece dokuz kapalı sinemanın olduğunu (Büyük, Kulüp, Saray, Lale, Köşk, Şenocak, Ferah, Albayrak, Tan) ve yabancı dublaj film gösteren sinemaların, bir hafta içinde, birden fazla sinema ile aynı yerli filmi oynayan sinemalardan daha fazla müşteri çektiğini belirtir..$^{58}$ Görüşmeciler arasında yabancı filmlere olan ilginin istisnai bir durum olmadığıı, altmışlı yıllarda yerel basında yer alan bazı anketler tarafından da desteklenmektedir. Örneğin, 1962'de "Yerli filmleri nasıl buluyorsunuz?" başlıklı bir ankete ilişkin 15 kişinin cevapları da yerli filme ilginin düşük olduğu hissini vermektedir. Yerli filmlerdeki konuların zayıf ve benzer oluşu ve oyuncuların tecrübesizliği, yerli filmlerin neden ilgi çekmediğine ilişkin olarak en çok tekrarlanan unsurlardır. Ankete katılan 15 kişiden bir tanesi yerli filmler içinde "sevda filmlerini" çok sevdiğini ve kaçırmadığını; bir diğeri sadece Türkan Şoray filmlerine gittiğini; bir tanesi de iyi yabancı film bulamayınca yerli filme gittiğini belirtmiştir. 15 kişinin içinde sadece bir kişi sinemaya "vakit öldürmek" için gittiğini, bu yüzden oynayan filmin önemli olmadığını söylemiştir. ${ }^{59} 1963$ 'te yapilan "Hangi tip filmleri seversiniz?" konulu bir başka ankete verilen 25 cevap ise, yerli filmlerden Zeki Müren ve Ayhan Işık filmlerine, bunun yanı sıra, cevap verenlerin deyimiyle "hissi" veya "saki" filmlere ilgi olduğunu göstermektedir. Bu anketin önemli bir özelliği de seyircilerin film tercihlerine ilişkin olarak toplumsal cinsiyet üzerinden bir genelleme yapılamayacağını göstermesidir. Örneğin bir kadın sekreter, bir yandan "aşki" filmleri diğer yandan ortaçağda geçen filmleri; bir başka kadın sekreter, gangster filmlerini sevebilmektedir. Ya da bir ev hanımı "uzak iklimlerde" ve "yabancı tabiat manzaraları arasında" geçen macera filmlerini sevebilir. Erkeklerin verdiği cevaplar,

lemdeki temsili ile ilgili bir inceleme için bkz. Erdoğan (2005).

58 (1966, Ağustos). Lamek Film Sinema Postası, 16, 3.

${ }^{59}$ Yerli Filmleri Nasıl Buluyorsunuz? (1962, 9 Kasım). Yeni Asır, 3. 
kadınlara nazaran daha tutarlı bir şekilde, macera filmlerini öne çıkarır görünmektedir. Macera filmlerini sevdiğini söylerken karşısına sevmediği tür olarak romantik filmleri koyanlara da rastlanır. Örneğin macera filmlerinden hoşlandığını söyleyen ve kaptan olduğu belirtilen bir erkek izleyici, "ağır romantik mevzulu" filmleri sıkıcı bulduğunu söylerken, kaynak ustası bir erkek şu yorumda bulunur: "Gangster filmlerine bayılırım. Kovboy filmlerini de severim. Fakat aşklı meşkli filmlerle Türk filmlerine hiç gitmem. İnsan sinir oluyor."60 Görüşmelerden elde edilen yorumlar, bu anketlerin sonuçlarıyla tutarlılık sergiler. Örneğin, yerli filmlerle ilgilenmeyip "ecnebi" filmlere gittiğini belirten, Mustafa Çalışık (65) sebebini şöyle özetler: "yapımları daha iyi geliyordu. Senaryoları daha iyi geliyordu. Mesela Love Story [Arthur Hiller, 1970], olmaz böyle bir şey. Yıldız Sineması'nda izledim. Ara oldu etrafa bakıyorum milletin gözleri dolmuş, suratlar kıpkırmızı." Çalışık, çok tutulan Hint filmlerinden de "çok konuştukları için" hoşlanmadığını belirtmiştir. Yerli film izleyicisinin genelde beğendiği düşünülen Hint filmlerini çok sevse de yerli filmleri sevmediğini söyleyen Süleyman Kalkan (73) ise aradaki farkı şöyle anlatır: "Hint filmlerinde dekorasyon var. Yerliler taklit ediyor. Avare mesela. Çok güzel sahneler var. Danslar." Bununla birlikte, Kalkan, yerli filmlerden Zeki Müren filmlerine "şarkıları için" gittiğini de belirtmiştir. Semiha Guvan (87) ise yabancı filmleri müzik açısından zengin bulur ve alttan alta kendisi için sinemanın yabancı sinema demek olduğunu ima eder: "Biz hep yabancı filmlere giderdik. Müziklerini çok severdik Avrupa sinemalarının. Amerikan filmleri, kovboy filmleri, hepsine gittik yani. Ve ben sinemayı çok severim." Aşağıda, toplu halde görüşmelere odaklanarak, görüşmeciler için sinemada film izlemenin anlamını, sinemalardaki seyir ortamını ve film izleme deneyimini zevkli kılan unsurları ele alıyoruz.

Altmışlı ve yetmişli yıllarda sıklıkla sinemaya giden Şükrü Yılmaz (70), kendisine sinemaya gündelik sıkıntılardan kaçmak için gidip gitmediği sorulduğunda, "Yok ya, macera olarak giderdik. Bu film kaçmaz seyrederiz derdik" şeklinde cevap vermiştir. Şeref Şakar (74) ise kendisi için sinemaya gitmenin anlamını, "demek ki bir şeyler görmek istiyordu insan. Değişik bir şeyler. Bir film gelirdi... Kuaförde çalışırken bir müşteri geliyor. Şeref Ylldız'da bir film var git onu gör" cümleleriyle açıklamaya çalışırken, kadın görüşmeci Tanzer Başer Ökte (65), "filmler önemliydi. Filanca filmler gelmiş, gittin mi diye şey olurdu" demiş, Ali

${ }^{60}$ Hangi Tip Filmleri Seversiniz? (1963, 30 Kasım). Yeni Asır, 3. 
Ulvi Tunalı (65) ise "boş vaktimizi geçirmek için değil, bir şeylerle donanıp geri gelmek için gidiyorduk. O zamanlar Amerika'dan filmler iki üç sene sonra geliyordu. Biz o filmleri özlemle bekliyorduk" açıklamasinda bulunmuştur. Bu yorumlardan, sinemaya bir filmin gelmesinin, o filmi gidip görmenin kendisinin başlı başına bir olay olduğu anlaşılır. Yorumlardan, görüşmecilerin hangi filmlere gideceklerine karar vermelerinde kulaktan kulağa bilginin önemli bir etki olduğu da görülür. Bunun yanı sıra, film reklam biçimleri arasında basın reklam ve ilanlarından çok sinemada gösterilen gelecek film fragmanlarının etkili olduğu da gözlemlenmiştir. Sinema önlerindeki afişler ve afişlerde geçen aktör isimleri de diğer etkili unsurlar arasındadır.

Gerek yerli sinemada gerekse ilgili akademik çalışmalarda, altmişlı ve yetmişli yıllarda, başta yazlık sinemalar olmak üzere, sinemanın seyir ortamı; gürültülü, şenlikli, evden getirilen yemeklerin (sarma-dolma) yendiği, perdede olup bitenlere yüksek sesle yorum ve tezahüratların yapıldığı, adeta karnavalesk bir ortam olarak tasvir edilegelmiştir (Öztürk, 2013, s. 21; Akbulut, 2014, s. 8; Liman, 2014, s. 114). Bu çalışma bağlamında yapılan görüşmeler, böyle bir seyir ortaminın, kapalı sinemalar ve yabancı filmler için her zaman her koşulda söz konusu olmadığını göstermektedir. Görüşmecilerin betimlemeleri, gittikleri sinemalarda sessiz ve dikkatli bir seyir pratiğinin varlığına işaret eder. Görüşmecilere film seyrettikleri salonun gürültülü olup olmadığı veya perdedeki olaylarla ve karakterlerle sesli bir diyaloğa girilip girilmediği sorulduğunda, pek çok görüşmeci, beklenenin aksine, "çıt çıkmazdı" cevabını vermiştir:

Hiç gürültü yoktu. Çıt bile çıkmazdı. Diyelim 500 kişi var. 500 kişiden çıt çıkmaz (Şeref Şakar, 74).

Sessizdi. Hiç konuşma olmazdı. Herkes güzel film olunca kendini kaptırıyor (Nevzer Gülersoy, 83).

Gürültü olmazdı. Hele Avare filmi falan oldu mu, çıt çılkmazdı yani. Pür dikkat filmi seyrederlerdi. Ara verdi mi ayyuka çıkardı sesler (Şükrü Yılmaz, 70).

Korkulu filmlerde çıt çıkmazdı. 1500-2000 kişi zangır zangır titriyor içerde. Adam korkuyor, hakikaten korkuyor. O Drakulalar, Christopher Lee, zangir zangir titriyor (Tolga Kazmirci, 58).

Yukarıdaki alıntılarda da görüleceği üzere, seyircilerdeki sessizlik ve dikkat, gidilen filmin doğasından da kaynaklanabilir. Sinemada yüksek sesle filme yorum yapma olayına tanık olmuş İhsan Helvacı'nın 
(70) açıklaması, bu sessizlik ve dikkatin filmin izlendiği seansla da bağlantılı olabileceğini düşündürtür: "Ali Kâhya diye bir abimiz vardı. O öpüşme sahnesi veya ilgi çekici bir sahnede 'takip et' diye bağırırdı. Bazen aşk sahnelerinde islık da olurdu. Hadi yürü be esprileri falan... Ama bunlar gündüzleri." Kapalı sinemalarda salondaki gürültü, konuşma veya eğlence miktarının sinemanın kimliğine, filmin türüne ve seansa göre değişebileceğini düşünebiliriz. Ancak şenlikli, yemeli içmeli, perdeyle konuşmalı seyir ortamının yazlık sinemalar, matineler ve yerli filmler için oldukça geçerli olduğundan emin olabiliriz:

Yaşlı hanımlar bağırırlardı: Anam gitti gitti öldü öldü... Yaşlılardan böyle sesler gelirdi biz de gülerdik (Gülören Sakız, 79).

Konu komşu yazlık sinemalara giderdik. Yiyecek, içecek, minder götürürdük. Oradan gazoz alırdık. Annem, kardeşim, ben... Babam işten sinemaya gelirdi. Biz önden giderdik daha iyi yer kapalım, daha iyi görelim diye. Onun yemeğini oraya götürürdük (Leyla Eskicioğlu, 65).

Sessiz ve dikkatli seyirciyi perdeye kilitleyenin ne olduğuna bakıldığındaysa, sıklıkla sinemaya gittiğini söyleyen Şeref Şakar'ın (74) yorumunda da görüleceği üzere, filmlerin yüksek yapımlı oluşundan gelen ihtişamları ön plana çıkar: "Filmler de şimdiki filmler gibi değil. Daha böyle ihtişamlı, çok masraflı. Tarihi konular. Şimdi öyle filmler çekmiyorlar. Bakıyorum pek inandırıcı da gelmiyor bana. On Emir [The Ten Commandments, Cecil B. DeMille, 1956], Ben Hur [William Wyler, 1959], insan 2-3 defa gidip seyretmek isterdi." Gençliğinde hep yabancı filmlere gittiğini söyleyen Kuddusi Temurtaş da (75), kendi içinde oldukça özgün bir yorumla, büyük yapımın öneminin altını şu sözlerle çizer:

Onlarda [yabancı filmlerde] iş makineleri falan çoktu. Merakım oydu benim. Ne makineler var. Şimdi gene bir iş makinesi filmi olsa ben ona giderim bakmaya. Eski filmler daha güzeldi. Anlam vardı. Eski adamlar arazide film çeviriyorlardı. Şununla bununla. Şimdikilerde hiçbir tane at mat eşek var mı? Bir odada film çeviriyorlar. Filmi açık arazileştireceksin. Millet araziyi görecek.

Aslında Temurtaş'ın "açık arazi" vurgusu yabancı filmlerin yerli seyircileri başka coğrafyalara ve kültürlere taşımasından duyulan hazla ilgilidir. Diğer görüşmecilerin yorumlarından da anlaşılabileceği gibi bu coğrafya ve kültürler güncel ya da gerçek olmak zorunda da değildir; tarihi veya mitolojik de olabilir. Görüşmeciler arasında en çok hatırlanan filmler dikkate alındığında, bunların, toplumsal hafızada uzun yıllar yer etmiş Avare filmi dışında, yüksek yapımlı epik filmler 
veya Hollywood klasikleri olduğu görülür [Ben Hur, On Emir, Spartaküs (Spartacus, Stanley Kubrick, 1960) Love Story, Rüzgâr Gibi Geçti (Gone with the Wind, Victor Fleming, 1939), vb.].

Filmlerin ihtişamının yanı sıra, görüntülerin inandırıcılığı ve gerçeklik hissi de seyircilerin hafızasında yer etmiş özellikler olarak göze çarpar. Örneğin, aşağıdaki alıntılarda görüleceği üzere, buzullarda geçen bir film, izleyene üşüme hissi verebilmiş; açık denizde batan bir gemi, gemiye binme korkusuna yol açabilmiş veya trajik bir aşk hikâyesi izleyicileri ağlatıp unutulmayacak izler bırakabilmiştir:

Bir film. Tahmin ediyorum buzullarda. İnanın ben filmi seyrederken üşüdüm. O kadar etki ediyordu demek ki (Şeref Şakar, 74).

Bir tane Poseydon Macerası (Poseidon Adventure, Ronald Neame, 1972) var, onun tesirinden kurtulamamıştım. Gemiye hiç binemiyorum o yüzden. Gemi batıyor bir tane, çok kalabalık. Koskoca gemiden beş kişi kurtuldu. Onun tesirindeyim yani hâlâ. Çok etkilendim o filmden. İlk zamanlarda Konak-Karşıyaka vapuruna bile korkarak biniyordum (Ayşe Vezir, 66).

Dramlarda mendillerle ağlanırdı. Arada bakarsın herkes ağliyor. Erkekler de ağliyor. Mesela ben Love Story'yi seyrederken ağladım. Öyle bir aşk filmi olmaz (Ahmet Erbilgici, 63).

Love Story oynadığında kız kanser oluyor ölüyor falan millet salya sümük gidiyordu içerde (Tolga Kazmirci, 58).

Filmlerdeki gerçeklik ve inandırıcılık hissinin, özellikle çocuklukta olmakla birlikte genel olarak bazı seyirciler arasinda da, sinema teknolojisine dair bir farkındalığın olmayışından, film görüntüsünün bir inşa ve temsil olduğunun bilinmemesinden kaynaklandığı da gözlemlenmiştir:

9-10 yaşında kovboy filmleri meşhur. Filmden çıkıyorum 10 gün sonra başka bir filme gidiyorum. A diyorum bu adam ölmüştü. O kadar etkisinde kalmışım ki. Tabi o zamanlar. Şimdiki çocuklara anlat gülerler. Sanki sinemada kişi öldüğü zaman öldü zannediyorduk. Ailece yazlık sinemaya gitmiştik. Kovboy filmiydi. Bir sırada insanlar oturmuş kadınlar falan. Atlar koşturuyor. Yanımdakiler yatın yatın dediler. Sanki o atlar üstüne geliyormuş gibi (Şeref Şakar, 74).

Çocukken ilk gittiğim film Ben Hur. At arabaları vardı. Korkardık üstümüze geliyorlar diye (Türkan Kaya, 69).

Biz mesela çocukken korkulu bir film oynaynnca perdeye kolay kolay yaklaşmazdık. O duruyordur arkada bir yerlerde diye. Nasıl yapıldığını bilmiyor ki insanlar filmlerin. Televizyon yok, bir şey yok. Perdede olanı 
gerçek sanıyordu insanlar. Bir filmde biri ölüp başka filmde görülünce e bu adam ölmemiş miydi diyen bile oluyordu yani (Tolga Kazmirci, 58).

Erol Taş [galaya] geldiğinde yuhalamışlardı. Kötü adamları biz gerçek sanıyorduk. Mesela Türkan Şoray bir filmde öldü öbür filmde gene var. Ama bu ölmemiş miydi? O kadar gerçek sanıyorduk (Leyla Eskicioğlu, 65).

Görüşmelerde özellikle yerli melodramlarla bir bağ kurmuş kadın seyircilerin varlığı da göze çarpar. Bu filmlerdeki aşk temsillerinin, modern yaşam biçimlerinin ve trajik duygu yapısının kadın seyirciyi etkileyen belli başlı öğeler olduğu görülür. Örneğin yukarıdaki alıntılar arasında, Poseidon filminden nasıl etkilendiğini anlatan Ayşe Vezir (66), konuşmasının devamında şu açıklamayı yapmıştır: "Ama bizim için Yeşilçam'dı aslında. Yabancı filmleri eşim seviyordu ondan gidiyordum. Aslında bizim için Yeşilçam çok değerliydi. Ağlıyorduk." Yeşilçam filmlerine ilişkin başka örnekler de mevcuttur:

Bize flörtün yasak olduğu zamanlar biz bu filmlerle flört ettik aslında. Böyle ortamda harika aşk hikâyeleri. Siyah beyaz filmler, Belgin Doruk, Ayhan Işık. Onların yaşadığı o güzel boğaz yalıları, köşkler, içindeki o şaşaalı hayat. Kadınların zarif giyimleri (Çimen Kanıer, 72).

Komşularla sinemaya gidiyorduk. Salya sümük ağlıyorduk. Dramları seyrediyorduk. Aşkları seyrediyorduk (Nurten Çatkın, 82).

Büyüklerin arabuluculukları, nasihatler. Kayınpeder araya girer, arabuluculuk yapar, kabul edersin. Mutlu son. Onlar bizi mutlu ediyordu. Biz mutlu son görmek isterdik (Gülören Sakız, 79).

\section{Filmden Geriye Kalanlar}

Ian Jarvie'nin de belirttiği üzere "Film seyretme, tecrübeleri zenginleştirmenin ve paylaşmanın bir yoludur. Filmde görülenleri hep birlikte konuşmak toplumda sosyal ve sosyalleştiren bir harekettir" (aktaran Liman, 2014, s. 111). Görüşmelerde, seyircilerin filmlerle ilişkisinin, sinemadan çıkınca biten bir ilişki olmadığı, perdede görülenlerin hayata taşındığı, gündelik hayatlarda sohbetlere konu olup, sosyalleşme imkânı sağladığı görülmüştür.

Filmleri ezberler arkadaşlarıma anlatırdım. Akşamları kapı önlerinde otururduk. Arkadaşlarım masal anlatırdı ben sinemayı anlatırdım. Babamla sinemadan dönerken de yol boyunca sinemayı konuşurdum (Nevzer Gülersoy, 83).

Sohbeti de edilirdi bunun. Hafta sonu şu filme gittik. Veya evde anlatılırdı. Şu filme gittik. Şöyleydi böyleydi falan diye. (Ali Ulvi Tunalı, 65) 
Sinemaya gidiyorduk sonra o bizim aramızda devam ediyordu. Anlatılıyordu. Ay şurası ne güzeldi. Ne kadar duyguluydu. Adam ne kadar seviyordu kadını. Nasıl ağliyordu (Nurten Çatkın, 82).

Görüşmelerde göze çarpan bir başka nokta da bazı seyircilerin, bu çalışma bağlamında özellikle kadınların, filmleri hayatlarına konuşmanın ötesine geçen şekillerde taşımalarıdır. Aşağıda kendisinden alıntı yapılan Alev Ersoy (78) örneğinde olduğu gibi, kadın seyirci ekonomik duruma da bağlı olarak, bir filmde gördüğü bir elbiseyi diktirebilir veya filmlerdeki karakterlerin araba kullanışlarını taklit etmeye çalışabilir. Kırklı ve elli yıllarda Hollywood'un İngiltere'deki kadın seyircileri üzerine olan etnografik çalışmasında Jackey Stacey, seyircilerin bu tür "taklit" biçimlerini "sinema-dışı özdeşleşme pratikleri (extra-cinematic identificatory practices)" olarak adlandırır (1994, s. 159).

İkbal Sineması'nda da çok güzel filmler oynardı. İtalyan filmleri. Çok güzeldi elbiselerini beğenirdik. Ona benzeyen elbiseler diktirmek için kumaşlarını ona göre almaya çalışırdık. Mesela Brigitte Bardot'nun bir filmi vardı. Böyle pembeli beyazlı çubuklu bir elbisesi vardı. Sonra ben böyle pembeli beyazlı böyle jarse kıvamında bir elbise diktirmiştim anneme hiç unutmuyorum. Onlardan çok etkileniyorduk tabi (Alev Ersoy, 78).

Yabancı filmlerdeki hayatları çok beğeniyorduk. Onlar bizim için çok modern hayatlardı. Arabalar vardı. A bir şey anlatıyım. Ehliyet için araba imtihanına girdim. Arabanin direksiyonunu bir o tarafa bir bu tarafa çeviriyorum. Ne yapiyorsun dediler. E filmlerde böyle sürülüyor ya de$\operatorname{dim}$ (Alev Ersoy, 78).

Ersoy'un söyledikleri, yabancı filmlerin bazı seyirciler tarafından modernite üstüne dersler gibi algılandıklarını da gösterir ve Akbulut'un, yapmış olduğu sözlü tarih incelemesinde vardığı sonuçlardan biri olarak, "Sinema modernleşmenin, modern yaşam pratiklerinin öğrenildiği ve yansitıldığı bir ortamdır" görüşünü destekler (2014, s. 8). Görüşmecilerden Semiha Guvan'ın (87) sözleri ise filmlerden öğrenilen müziklerin gündelik hayata nasıl taşındığına örnektir: "Tayyare Sineması'nda çok güzel filmler oynardı. Müzikal filmler. Ezberlerdik onları. Onlarla dans etmeye çalışırdık; o müzikle".

Sinemanin toplumsal deneyimi sadece sinemada film izlemekten ibaret değildir. Sinema kültürü ve deneyimi, basın gibi film dışı kanallar aracılığıyla, sinema salonu dışında yeniden üretilip yaygınlaştırılır. Ellis, özellikle magazin basının, sinema ve yıldızlarla ilgili haberler, dedikodular, röportaj ve biyografilerle film endüstrisini destekleyen bir 
yan kol olarak görülmesi gerektiğine değinir (1982, s. 91). Bu tür içeriğin, Türkiye'de olduğu gibi İzmir basınında da ellilerden itibaren yaygınlaştığı görülür. Bununla birlikte, bu çalışma kapsamında görüşülen kişilerin sinemanın bu boyutuyla pek ilgilenmemiş oldukları görülmüştür. Örneğin, sinema artistlerinin özel hayatlarıyla ilgilenmediğini, resimlerini toplamadığını söyleyen Mustafa Çalışık (65), sinemayla ilişkisini "sadece film izliyorduk" diyerek özetlemiştir. Çalışık'ın açıklaması, kadınlar da dâhil olmak üzere, diğer görüşmeciler için de geçerli görünmektedir. Kadınlardan sadece Alev Ersoy (78), o da biraz düşündüğünde, Shirley Temple resimleri topladığını söylemiştir: "Ben Shirley'leri topluyordum, çikletlerden çıkıyordu. Onları çok severdim, onları topluyordum. Başka bir şey toplamadım."

\section{Sonuç ve Tartışma}

Türkiye genelinde altmışlı ve yetmişli yılların canlı sinema ortamının, yetmişli yılların ortasından itibaren, gerek ülkedeki siyasi ve sosyal değişimler, gerekse sinema sektöründe yaşanan ekonomik krizler nedeniyle dönüşüme uğradığı genel bir görüştür. ${ }^{61} \mathrm{Bu}$ durum, İzmir için de geçerlidir. 1969 yllı sonundan itibaren yabancı filmlerle başlayıp yerli filmlerle devam eden "seks furyası"; ${ }^{\prime \prime 2}$ yetmişli yılların ortasına doğru kentte televizyon yayınının yaygınlaşması; ${ }^{63}$ yetmişli yılların başından itibaren Türk lirasına yapılan devalüasyonların (Tunç, 2012, s. 133) yanı sıra 1974'te film ithalatına getirilen sinırlamalar ${ }^{64}$ ve 1979 'da ilk video kulübün açılması ${ }^{65}$ İzmir'in sinema ortamını ve kültürünü dönüşüme uğratan ana etmenler olarak göze çarpar. Bu dönüşümden her sinema gibi Yıldız Sineması da etkilenir. Sinema'nın 1982 yılına dek müdürlüğünü yapan Oğuz Işıkalp'in oğlu Osman Işıkalp (51), Yıldız'daki sinema kültürünün yetmişli yılların ortasına kadar devam ettiğini, takip eden yıllarda, "elde olmayan nedenlerle," sinemanın program kalitesinin ve

\footnotetext{
${ }^{61}$ Bu dönüşümün Türkiye genelindeki özeti için Bkz. Tunç (2012, s. 133-40).

${ }^{62}$ İzmir'de Seks Filmi Gösteren Sinemada Tek Boş Koltuk Yok (1969, 31 Aralık). Yeni Asır, 1; İzmir Polisi Açık-seçik Filmlere Savaş Açtı (1972, 22 Şubat). Yeni Asır, Sarmaşık eki, 1; Seks Filmleri de Tarihe Karışıyor (1974, 20 Ocak), Yeni Asır, Sarmaşık eki, 1; Seks Filmleriyle Mücadele Edin (1979, 21 Aralık). Yeni Asır, Sarmaşık eki, 1.

${ }^{63}$ Televizyon Öldü Yaşasın Sinema (1974, 15 Ocak). Yeni Asır, Sarmaşık eki, 1.

${ }^{64}$ Film İthalinde Yapılan Değişiklik Yürürlüğe Girdi (1974, 1 Aralık). Yeni Asır, Sarmaşık eki, 1; Yabancı Film İthalindeki Permi Konusu Halledilmezse Türk Filmlerine Rağbet Artacak (1974, 25 Eylül). Yeni Asır, Sarmaşık eki, 1.

${ }^{65}$ İzmir'de Video Kulüp Kuruldu (1979, 26 Aralık). Yeni Asır, Sarmaşık eki, 1.
} 
buna bağlı olarak izleyici profilinin giderek düştüğünü belirtir. Film ilanları, 1972 yılından itibaren Uzakdoğu dövüş filmlerinin ve erotik filmlerin Yıldız Sineması programlarına girdiğini gösterir. Yüksel Kazmirci, adını hatırlamadığı bir Uzakdoğu dövüş filminin günlük 11,000 izleyiciyle, Avare'yi de geçerek hasılat rekoru kırdığını belirtmiştir. ${ }^{66}$ 1978 yllından itibaren ise, sinemanın, arabesk filmler de dâhil olmak üzere tamamen yerli film gösterimine geçtiği ve 1980 yllına dek bu şekilde devam ettiği saptanmıştır. Sinema, 1988 yılı Kasım ayında tamamen kapanır. 1989 Ocak ayında Yıldız Sineması artık "Yıldız Spor Tesisleri" olmuş ve başta halı saha olmak üzere, bilardo ve masa tenisi salonu olarak hizmet vermektedir.

Yıldız sineması örneğinde de görüleceği üzere, İzmir'in sosyal ve kültürel hayatının önemli bir kamusal alanı ve popüler bir gündelik hayat pratiği olan sinema ile uzun ve canlı ilişkisi zaman içinde tamamen kaybolur. Film göstererek ayakta kalamayan sinema salonları, kentsel dönüşüm süreçlerinden de etkilenerek yerlerini iş hanlarına, apartmanlara veya halı saha gibi sinema dişı işlevlere sahip yapılara bırakır. Bugün İzmir'in kayıp sinemaları üzerine olan eleştirel ve popüler söylem nostaljik bir yakınmanın ötesine geçememektedir. Bu çalışmada, kısmen de olsa, bu kayıp tarihi en azından söylemsel olarak yeniden inşa etmeye ve en canll dönemlerinde İzmir'de sinemanın sosyal deneyimini anlamaya çalıştık. Bir olay olarak sinemaya gitmeye ve sinemada film izlemeye atfedilen anlamları; sinema salonlarının film gösterimi ve film izleme ötesinde eylemlere ve performanslara ortam oluşturan kamusal mekânlar oluşunu; farkl seyir pratiklerini sözlü tarih görüşmeleri aracılığıyla açığa çıkardık. Bu teşebbüslerin yanı sıra, bu çalışmanın en önemli bulgusu, ele alınan dönemlerde kentteki sinema seyircisinden homojen bir kitle ve sinemanın sosyal deneyiminden tek tip bir deneyim olarak bahsedilemeyeceğidir. Gerek gazete taramaları gerekse yapılan görüşmeler; yaş, toplumsal cinsiyet, sosyoekonomik sınıf ve beğeni (taste) farklllıklarından kaynaklı farklı deneyim süreçlerine işaret etmektedir. Daha önce yapılan benzer çalışmalardan farklı olarak, bu çalışma, bu farklılıkları tek bir "sosyal deneyim" potasında eritmek yerine görünür kılmaya çalışmıştır. Sinema bir toplu eğlence

\footnotetext{
${ }^{66}$ Ürük bu filmin Wang Yu filmlerinden biri olduğunu belirtir (2013c, s. 81). Gazetedeki film ilanlarına bakıldığındaysa söz konusu filmin iki hafta gösterimde kalan, başrollerde Li Ching ve David Chiang'ın olduğu Kolsuz Kahramanın İntikamı (The New One-Armed Swordsman, Chang Cheh, 1971) adlı film de olabileceği düşünülür.
} 
ve haz alanı olduğu kadar, farklı karşılaşmaların ve çatışmaların yaşandığı bir mücadele alanıdır da.

\section{Kaynakça}

Akçura, G. (2016, Kış). Yıldız Diye Bir Sinema Vardı... KNK Kent Konak Dergisi, 26, 28-33.

Allen, R. C. (1990). From Exhibition to Reception. Screen, 31(4), 347-356.

Allen, R. C. \& Gomery, D. (1985). Film History: Theory and Practice. New York: McGraw Hill.

Akbulut, H. (2014). Sinemaya Gitmek ve Seyir: Bir Sözlü Tarih Çalışması. Elektronik Mesleki Gelişim ve Araştırma Dergisi, 2, 1-16.

Altınöz, M.Ö. (2015). Endüstri Kenti Karabük'ün Sosyal Yaşantısının Şekillenişinde Yenişehir Sineması'nın Rolü. İnsan ve Toplum Bilimleri Araştırmaları Dergisi, 1, 83-99.

Aydın, H. (2008). Sinemanın Taşrada Gelişim Süreci: Konya'da İlk Sinemalar ve Gösterilen Filmler (1910-1950). Selçuk Üniversitesi Sosyal Bilimler Enstitüsü Dergisi, 19, 61-74.

Beşikçi, O. (2015, 3 Kasım). Basmane'de Bir Yıldız. Kentyaşam. http:// www.kentyasam.com/soylesiler-ksdty-87.html. 8 Mart 2016.

Biltereyst, D., Lotze, K. \& Meers, P. (2012). Triangulation in Historical Audience Research: Reflections and Experiences from a Multi-methodological Research Project on Cinema Audiences in Flanders. Participations, 9(2), 692-715.

Biltereyst, D. Maltby, R. \& Meers, P. (2012). Cinema, Audiences and Modernity: New Perspectives on European Cinema History. London: Routledge.

Biltereyst, D. \& Meers, P. (2016). New Cinema History and the Comparative Mode: Reflections on Comparing Historical Cinema Cultures. Alphaville: Journal of Film and Screen Media, 11, 13-32.

Boran, T. (2015). Erken Cumhuriyet Döneminde Taşrada Sinema Seyri: Çankırı Örneği. İletişim Kuram ve Araştırma Dergisi, 41, 257-276.

Corrigan, P. (1983). Film Entertainment as Ideology and Pleasure: A Preliminary Approach to a History of Audiences. J. Curran \& V. Porter (Ed.), British Cinema History (s. 24-35). London: Weidenfeld \& Nicolson. 
Ellis, J. (1982). Visible Fictions. London \& New York: Routledge.

Erdoğan, N. (2005). The Making of Our America: Hollywood in a Turkish Context. M. Stokes \& R. Maltby (Ed.), Hollywood Abroad: Audiences and Cultural Exchange (s. 113-124). London: British Film Institute.

Erdoğan, N. (2010). The Spectator in the Making: Modernity and Cinema in Istanbul 1896-1928. D. Göktürk, L. Soysal \& İ. Türeli (Ed.), Orienting Istanbul: Cultural Capital of Europe? (s. 129-143). London: Routledge.

Ergir, E. E. (1999). Unutamadığım Karşıyakam ve İzmir'im. İzmir: Tükelmat.

Ertaylan, A. (2013). Yeşilçam Döneminde Van'ın Sinema Kültürü. Turkish Studies, 8(8), 1839-1857.

Gölgesiz Gedikler, H. (2006). 1950-1960 Yllları Arasında İzmir'de Gündelik Yaşam. (Yayınlanmamış Doktora Tezi). Dokuz Eylül Üniversitesi Atatürk İlkeleri ve İnkılap Tarihi Enstitüsü, İzmir.

Gürata, A. (2007). Hollywood in Vernacular: Translation and Cross-cultural Reception of American Films in Turkey. M. Stokes, R. C. Allen \& R. Maltby (Ed.), Going to the Movies: Hollywood and the Social Experience of Cinema (s. 333-347). Exeter: University of Exeter Press.

Gürata, A. (2010). 'The Road to Vagrancy': Translation and Reception of Indian Cinema in Turkey. BioScope: South Asian Screen Studies, 1(1), 67-90.

Kaya, D. (2016). From Cine Pallas to Tayyare Apartment Block: Urban Space, Identity, and Memory. A. L. Kırtunç, M. Erdem, A. Silkü \& K. G. Fry (Ed.), Culture and Space (s. 65-73). İzmir: Ege Üniversitesi.

Liman, A. S. (2014). Gaziantep'te Sinema, Seyir ve Seyirci (1923-1980). İstanbul Üniversitesi İletişim Fakültesi Dergisi, 47, 97-124.

Makal, O. (1999). Tarih İçinde İzmir Sinemalar. İzmir: Güsev.

Maltby, R., Biltereyst, D. \& Meers, P. (2011). Explorations in New Cinema History: Approaches and Case Studies. Malden: Wiley-Blackwell.

Mayne, J. (1993). Cinema and Spectatorship. London \& New York: Routledge.

Özdemir, T. (2012). Çocukluğumun Alsancak'ı. İzmir: Konak Belediyesi. Öztürk, S. (2013). Türkiye'de Sinema Mekânlarını Sözlü Tarih Üzerinden Anlamak. Milli Folklor, 98, 19-31. 
Stacey, J. (1994). Star Gazing: Hollywood Cinema and Female Spectatorship. London \& New York: Routledge.

Stokes, M. \& Maltby, R. (Ed.). (1999a). American Movie Audiences: From the Turn of the Century to the Early Sound Era. London: British Film Institute.

Stokes, M. \& Maltby, R. (1999b). Identifying Hollywood's Audiences: Cultural Identity and the Movies. London: British Film Institute.

Stokes, M. \& Maltby, R. (2001). Hollywood Spectatorship: Changing Perceptions of Cinema Audiences. London: British Film Institute.

Stokes, M. \& Maltby, R. (2004). Hollywood Abroad: Audiences and Cultural Exchange. London: British Film Institute.

Tunç, E. (2012). Türk Sinemasının Ekonomik Yapısı. İstanbul: Doruk.

Ürük, Y. (2003, Mart). Anılarımın 'Beş Dakika Araları'. İzmir Kent Kültürü Dergisi, 6, 24-139.

Ürük, Y. (2011, Ekim). Yazlık Sinema Cenneti İzmir 5. İzmir Life, 122, 52-54.

Ürük, Y. (2012, Nisan). Üç Sinema Vadisi. İzmir Life, 128, 52-53.

Ürük, Y. (2013a, Ocak). Asri ve Yıldız Sinemaları. İzmir Life, 137, 54-55. Ürük, Y. (2013b, Mart). Açılır Tavanlı Sinema... İzmir Life, 139, 56-57.

Ürük, Y. (2013c, Nisan). Yıldızların Altındaki Yıldız Sineması. İzmir Life, 140, 80-81.

Ürük, Y. (2013d, Mayıs). Asri ve Mezarlıkbaşı Sinemalarının Sonu. İzmir Life, 141, 64-65.

Yentürk, A. (2003, Mart). İzmir'in Ruhu: Sadık Yemni ile Söyleşi. İzmir Kent Kültürü Dergisi, 6, 40-47. 


\section{Görüşmeler:}

Alev Ersoy (78), 10 Şubat 2017

Ali Ulvi Tunalı (65), 22 Şubat 2017

Ayşe Vezir (66), 21 Aralık 2016

Bedriye Eriş (91), 17 Ocak 2016

Ahmet Erbilgici (63), 5 Eylül 2016

Çimen Kanıer (72), 20 Aralık 2016

Ferruh Özdemir (67), 14 Ekim 2016

Figen Saygin (60), 27 Kasım 2016

Gülperi İzci (81), 17 Ocak 2016

Gülören Sakız (79), 19 Aralık 2016

Gülseren Çiftçi (82), 20 Aralık 2016

İhsan Helvacı (70), 5 Eylül 2016

Kuddusi Temurtaş (75), 14 Aralık 2016

Leyla Eskicioğlu (65), 19 Eylül 2016

Mehmet Bazan (65), 18 Aralık 2016

Mustafa Çalışık (65), 3 Şubat 2017

Nadide Özdemir (63), 14 Ekim 2016

Nevzer Gülersoy (83), 30 Eylül 2016

Nurten Çatkın (82), 17 Ocak 2016

Osman Işıklap (51), 7 Ekim 2016

Şükrü Yllmaz (70), 7 Eylül 2016

Oya Düzgün (54), 27 Kasım 2016

Rüstem Çetin (82), 26 Ekim 2016

Sadullah Kement (66), 19 Eylül 2016

Semiha Guvan (87)، 17 Ocak 2016

Sıdıka Kaçuna (75), 18 Aralık 2016

Süleyman Kalkan (73), 19 Ekim 2016

Şeref Şakar (74), 9 Eylül 2016 
Dilek Kaya | Eski İzmir Sinemaları ve Yıldız Sineması: Mekan, Toplum, Seyir

Tanzer Başer Ökte (65), 17 Ocak 2017

Tarık Kara (75), 21 Ekim 2016

Tolga Kazmirci (58), 8 Mart 2016

Türkan Kaya (69), 17 Aralık 2016

Ülfet Işıklap (74), 12 Ekim 2016

Yüksel Kazmirci (87), 15 Mart 2016 